\title{
Dotazník zmatení rolí pro adolescenty: Sdělení o vývoji sebeposuzovací metody ${ }^{1}$
}

\author{
LenKa PivodovÁ2, Petra DaŇSOVÁ2, LenKa LaCinovÁ \\ 2 Katedra psychologie, Fakulta sociálních studií Masarykovy univerzity
}

\begin{abstract}
Abstrakt: Cílem studie bylo vyvinout dotazník, který by zachytil míru zmatení rolí tak, jak ji aktuálně prožívají adolescenti. Postup tvorby dotazníku je popsán prostřednictvím tří studií, které na sebe navazují. Ve studii I bylo pilotováno 9 sebehodnotících položek dotazníku na vzorku adolescentů ( $n=56 ; 13-17$ let; $M=15,02 ; S D=1,8 ; z$ toho $65,5 \%$ dívky). Byla ověrena vnitřní konzistence a faktorové př́slušnosti položek do dvou faktorů - instrumentální zmatení rolí a emocionální zmatení rolí. Ve studii II bylo pilotováno 16 položek dotazníku (stávající ze studie I, pozměněné a doplněné) na vzorku adolescentů ( $n=154 ; 12$-19 let; $M=15,23$; SD = 2,02; 61,7 \% dívky). Bylo zde odlišeno zmatení rolí směrem $k$ otci a matce zvlášt', položky jsou rozděleny do tř́ faktorů: instrumentálního zmatení rolí, emocionálního zmatení rolí $v$ dyádě matka/dítě a emocionální zmatení rolí otec/dítě. Vzhledem $k$ tomu, že obsahově podobné položky pro matku a otce byly administrovány po sobě a sdílely rozptyl, který nebyl možný vysvětlit jejich př́slušností do škál, byl dotazník s odlišným pořadím položek podroben následnému zkoumání v rámci kvantitativního výzkumu ve studii III. Výzkumný soubor tvořili studenti střední odborných škol a učilišt' (n=293; 15-21 let, M=16,23; 67,6 \% dívky). Byla provedena konfirmační faktorová analýza a byla ověřena faktorová struktura dotazníku ZRA.
\end{abstract}

Klíčová slova: Zmatení rolí; dotazník; adolescence; sebeposuzovací metoda; dyády rodič-dítě

\section{Úvod}

Zmatení rolí (role confusion), které je také označováno např. jako parentifikace (parentification) či záměna rolí (role reversal), je relativně častým jevem, který se vyskytuje $\mathrm{v}$ rodinných systémech $\mathrm{v}$ různé intenzitě. Jedná se o situace, $\mathrm{v}$ nichž je dítě tlačeno do

\footnotetext{
${ }^{1}$ Studie vznikla v rámci řešení projektu GAČR Vývoj vztahů v adolescenci: Využití perspektivy citové vazby, dynamicko-systémového přístupu a metody časových řad (GA16-03059S) a projektu specifického výzkumu DOMOV, CESTY, PARTICIPACE: 2019 (MUNI/A/1138/2018).

${ }^{2}$ Katedra psychologie, Fakulta sociálních studií MU, Joštova 10, 602 00, Brno Doručeno do redakce: 25. 11. 2019
} 
L. Pivodová, P. Daňsová, L. Lacinová: Dotazník zmatení rolí pro adolescenty: Sdělení o vývoji sebeposuzovací metody

přebírání rolí či kompetencí v rodině, které jsou pro něj vývojově neadekvátní (Jurkovic, 1997; Vulliez-Coady, Solheim, Nahum, \& Lyons-Ruth, 2016). Dle Macfieové, Brumariuové a Lyons-Ruthové (2015) je zmatení rolí úzce spojeno s oslabením rodičovské role, kdy rodič ustupuje ze své role a dítě toto chybějící místo zaplňuje, přebírá potřebné kompetence, které se z rodinného systému vytratily. Rodina tedy funguje jako organizmus, snaží se udržet či obnovit rovnováhu uvnitř systému. Bylo opakovaně prokázáno, že narušení hranic rodinného systému může mít vliv na vývoj a adaptaci dětí. U dětí se mohou objevit internalizované a externalizované problémy v chování, v dospívání a dospělosti zvýšená depresivita, problémy s nízkým sebevědomím, častější somatizace (např. Grych \& Fincham, 1990; Macafie, Houts, McElwain, \& Cox, 2005). Z dosavadních zjištění vyplývá, že tento negativní efekt působí tehdy, kdy jsou nároky na zvládání rodičovských kompetencí výrazným způsobem pro dítě vývojově neadekvátní a pokud je zároveň tato situace dlouhodobá. Pro dítě tak představuje nadměrnou zátěž a je pro něj velmi náročná. Pokud dítě přebírá povinnosti či kompetence krátkodobě a je schopno je dobře zvládat, může docházet spíše k pozitivním dopadům na jeho psychický stav a vývoj (např́klad zvýšení sebehodnocení - Van der Milj \& Vingerhoets, 2017; Lewandowska-Walter, Borchet, Rostowska, Polomski, \& Peplinska, 2017). Faktorem, který vstupuje do podoby vnímání přebírání rodičovských kompetencí dětmi, je kulturní a sociekonomický kontext (VuliezCoady, Solheimm, Nahum, \& Lyons-Ruth, 2013). Dle ekologické teorie (Bronnfebrenner, 1979) vývoj dítěte ovlivňuje jak jeho blízké prostředí (vztahy s rodiči, vztahy mezi rodiči, historie rodiny) tak vzdálenější kontext, jako jsou společenské a kulturní normy. V kulturách, které jsou tradičně kolektivistické, kde rodiny žijí více pospolu, se jednotlivé povinnosti i role přirozeně mezigeneračně přebírají. Např. dle Hardwaye a Fuligniho (2006) adolescenti z Mexika a Latinské Ameriky tráví pomáháním v domácnostech více času oproti svým vrstevníkům z evropských zemí.

Zmatení rolí má tedy mnoho podob, od přechodné, krátkodobé a tedy méně náročné po dlouhodobou a zatěžující. Pro podobu zmatení rolí je důležitá celá řada faktorů - jedná se o strukturu rodiny (zda je úplná, rodič je osamělý apod.) a její socioekonomické zařazení, dále pak o charakteristiky dynamiky a fungování rodiny (např. koheze, jasnost a podoba hranic mezi subsystému, flexibilita, vřelost apod.). Byng-Hall (2002) na základě svých zkušeností z rodinné terapie považuje výskyt zmatení rolí v rodinách za mnohem více běžný, než se běžně předpokládá. Za důležitou pokládají detekci tohoto fenoménu v rodinách, a tím pádem i tvorbu nástroje, který by zjišt’oval míru a typ zmatení rolí v rodinách, Hooperová, Doelherová, Wallaceová a Hannahová (2011). Tato studie představuje tvorbu dotazníku, který by měl zachycovat fenomén zmatení rolí z perspektivy dospívajících. Při jeho tvorbě vycházíme ze zastřešujícího konceptu, kterým je zmatení rolí (role confusion), pod který lze zařadit jak parentifikaci (dítě jako rodič - child as a parent), spousifikaci (dítě jako partner child as a spouse) a také situaci, kde je dítě pro rodiče v roli kamaráda (child as a peer). Jednotlivé koncepty (jako je parentifikace, převrácení rolí, spousifikace, narušení hranic 
L. Pivodová, P. Daňsová, L. Lacinová: Dotazník zmatení rolí pro adolescenty: Sdělení o vývoji sebeposuzovací metody

rodinného systému), mají společný aspekt, kterým je výměna rolí mezi rodičem a dítětem bud' v psychické - emocionální podobě nebo/a instrumentální podobě (Macfie et al., 2015). K použití termínu zmatení rolí (role confusion) se přiklání také Vulliez-Coadyová, Obsuthová, Torreiro-Casalová, Ellertsdottirová a Lyons-Ruthová (2013), kteří se domnívají, že v tomto termínu je zahrnuta míra, jak moc rodič ustupuje ze svých rolí a jak moc dítě přebírá zodpovědnost $\mathrm{v}$ dyádě rodič - dítě oproti převrácení rolí (role reversal), kde se jedná o kompletní „výměnu“ rolí, což lze považovat za extrémní podobu v rámci kontinua zmatení rolí. K jednotnému a zastřešujícímu pojmu zmatení rolí se přikláníme také na základě našich dosavadních zjištění při mapování fenoménu spousifikace (více viz Pivodová \& Lacinová, 2016).

\section{Odlišnosti v jednotlivých rodičovsko-dětských dyádách}

Dosavadní zjištění naznačují, že dyadické vztahy mezi rodiči a dětmi nabývají kvalitativně odlišné podoby v kontextu pohlaví, tzn., zda se jedná o vztah matka-dcera, matka-syn, otecdcera, otec-syn. Většina studií (např. Koerner, Wallace, \& Jacobs-Lehman, 2004; Nuttall, Valentino, \& Borkowski, 2012; Trentacosta, Criss, Shaw, Lacourse, Hyde, \& Dishion, 2011) se zaměřuje na vztah mezi matkou a dítětem. Pravděpodobně mimo jiné i proto, že po rozvodu, což je jeden z výrazných faktorů pro rozvoj narušení hranic rodinného systému a pro rozvoj parentifikace (např.: Jurkovic, Thirkield, \& Morrell, 2001, Afifi \& Schrodt, 2003), jsou matky stále těmi, kterým bývá nejčastěji dítě přiděleno do péče, nebo prostě proto, že otcové rodiny s dětmi opouští častěji než matky. Několik studií, které sledovaly oba rodiče (Amato \& Afifi, 2006; Hetherington, cit. dle Perrin, Ehrenberg, \& Hunter, 2013) dokládá, že matky sice více zapojují děti do emocionální parentifikace než otcové, nicméně pokud otcové výrazněji citově spoléhají na své děti, negativní dopady v oblasti emocí jsou větší, než tomu je u matek (Hetherington, cit. dle Perrin, Ehrenberg, \& Hunter, 2013). Je pravděpodobné, že tento rozdíl je způsoben tím, že z hlediska genderově stereotypního vnímání otců se jedná o netypickou situaci. Když otec potřebou emoční opory od dítěte projevuje jistou „slabost“, může to způsobovat vyšší míru emočního stresu pro dítě. Dle výsledků Perrinové, Ehrenbergové a Huntera (2013) jsou matky mnohem náchylnější k parentifikaci dětí než otcové, otcové totiž obecně na své děti spoléhají mnohem méně. Studie tedy potvrdila zvýšené riziko parentifikace v dyádě matka-dítě než otec-dítě. Zapojení otce do výchovy dítěte má také vliv na míru parenifikace (Fullinwider-Bush \& Jacobvitz,1993). Pokud se otec do výchovy zapojuje, tak míra parentifikace ve vztahu matka-dítě klesá. Doposud je málo známo o tom, jak přispívají otcové ke vzniku zmatení rolí. Vztahy a jejich dynamika v rozvedených rodinách zvyšuje riziko, že rodiče mohou vyžadovat od dětí emocionální podporu. Výzkumníci se doposud spíše zabývali následky zmatení rolí, ale nezahrnovali do výzkumů, zda se jednalo o matky či otce, nebo do svých výsledků zahrnovali pouze matky. Domníváme se, že jde o další mezeru v poznání, kterou je potřebné zaplnit.

\section{Měřící nástroje zaměřené na výpovědi dětí}


L. Pivodová, P. Daňsová, L. Lacinová: Dotazník zmatení rolí pro adolescenty: Sdělení o vývoji sebeposuzovací metody

Způsobem, jak zjišt'ovat a měřit míru zmatení rolí/parentifikace v rodinném systému, se zabývalo od 80. let minulého století několik výzkumníků. Georgeová, Kaplanová a Mainová (1984) byly jedny z prvních, kteří zahrnuli dotazování na převrácení rolí (role reversal) v rámci Adult Attachment Interview (Macfie, Brumariu, \& Lyons-Ruth, 2015). Tato metoda je primárně zaměřena na reprezentaci vazby v dětství. Je svým charakterem retrospektivní, měří tedy převrácení rolí v průběhu dětství, ale jedná se o zpětné hodnocení z pozice dospělého. Jinou retrospektivní metodou na detekci parentifikace v dětství, která má podobu sebehodnotící škály, je Parentification Scale, kterou vyvinuli Mikaová, Bergner a Baum (1987).

V následujících letech se většina výzkumníků snažila měřící nástroje vylepšovat, nicméně stále se jednalo o retrospektivní sebehodnotící metody, kdy již dospělí retrospektivně hodnotili situaci v rodině během svého dětství. Parentification Questionnaire - Adult vyvinuli Sessions a Jurkovic (1986, cit. dle Jurkovic, 1997). Modifikovanou verzí pro dospívající je Godsallův a Jurkovicův Parentification Questionnaire - Youth (1995, cit. dle Jurkovic, 1997). Jedná se o sebehodnotící dotazník pro děti a mládež, který ovšem není dohledatelný v plném znění, není tedy známo, pro jaké věkové rozpětí byl používán a s jakými výsledky. Z výše zmíněného dotazníku Sessiona a Jurkovice Parentification Questionnaire - Adult a na základě teorie rodinného systému vyvinuli Jurkovic a Thirkied v roce 1998 další tř̌icetipoložkový sebehodnotící dotazník, který měl zachycovat i míru parentifikace. Parentification Questionnaire $(P Q)$ je koncipován opět jako retrospektivní, byl tedy určen pro dospělé osoby, které subjektivně hodnotily dle vzpomínek, do jaké míry přebíraly v dětství kompetence za rodiče. PQ zachycuje tři faktory: instrumentální parentifikaci (instrumental parentification), emocionální parentifikaci (emotional parentification) a vnímání nespravedlnosti (percieved unfairness). První dva faktory zachycují typy parentifikace. Subškála vnímání nespravedlnosti dle Jurkovice, Morrella a Thirkielda (1999) měří vzájemný vztah s rodiči (např. „Z nějakého důvodu pro mě bylo obtížné rodičưm důvěrovat."; „Členové rodiny pro mě měli velké porozumění."; Jurkovic \& Thirkield, 1998, cit. dle Hooper \& Wallace, 2010, str. 61). Tato subškála popisuje míru, v jaké vnímá zkoumaná osoba parentifikaci jako spravedlivou.

V roce 2011 vyvinula Hooperová spolu s Doehlerovou, Wallaceovou a Hannahovou The Parentification Inventory. Výzkumnice postrádaly v metodě Parentification Questionnaire zohlednění kulturního kontextu. Upozornily, že vnímání spravedlnosti/nespravedlnosti může být kulturně podmíněné. To znamená, že vnímání nepravedlnosti je ovlivněno obecně přijímanými normami společnosti a očekáváním okolí. Další aspekt, který chtěly tyto výzkumnice do měření doplnit, byl směr - ke komu parentifikace směřuje. Jejich cílem tedy bylo vytvořit dotazník, který by zahrnoval jak detekci procesů instrumentálního a emocionálního chování, tak kulturní kontext a „směr“ parentifikace (zda je směřována k sourozenci či rodiči). Prostřednictvím explorační a konfirmační faktorové analýzy byly identifikovány z položek tři faktory: 1) parentifikace směřovaná na rodiče (parent focused 
L. Pivodová, P. Daňsová, L. Lacinová: Dotazník zmatení rolí pro adolescenty: Sdělení o vývoji sebeposuzovací metody

parentification); 2) parentifikace směřovaná na sourozence (sibling focused Parentification); a 3) výhody parentifikace (perceived benefits of parentification). Jedná se také o sebehodnotící restrospektivní nástroj.

Výzkumnící se dále pokoušeli zjišt'ovat míru zmatení rolí nejen retrospektivně, ale také aktuálně - přímo od dětí a adolescentů. Tyto metody shrnují Vuliez - Coadyová et al. (2013). U dětí mezi 2,5-8 lety zmiňují použití hodnocení kresby, či pozorování interakce mezi rodičem a dítětem při hře s panenkou (doll play stories), kdy je zaznamenáváno, do jaké míry dítě rodiče kontroluje a řídí. Byly zde detekovány dva typy chování, a to řízené pečující chování (controling - caregiving behaviour) a řízené trestající chování (controling punitive behaviour) (Cassidy \& Marvin, 1992). Sebehodnotící metodou pro adolescenty je dotazník Inadequate Boundaries Questionnaire (IBQ) výzkumníků Mayselessové a Sharfové (2009). Ten měří vnímanou míru narušení hranic mezi dospívajícím a rodičem. Zmíněné metody jsou určeny bud' pro mladší děti, nebo neměří fenomén zmatení rolí. V současné době tedy chybí metoda, která by byla zaměřená konkrétně na zmatení rolí a jeho projevy, zároveň detekovala tento fenomén aktuálně u adolescentů.

\section{Měřící nástroje zaměřené na výpovědi rodičů}

Převažující výzkumné zaměření na výpovědi dětí, a to převážně z retrospektivní perspektivy, způsobilo vznik jisté mezery v poznatcích týkajících se problematiky narušení hranic v rodinných systémech. Vuliez-Coadyová s kolektivem (2013) upozorňují, že studie zaměřené na dyadické vztahy a zmatení rolí $\mathrm{v}$ rodině $\mathrm{v}$ různých podobách využívaly převážně pohled dítěte, a to jak perspektivu samotných dětí vypovídajících o aktuální situaci, ale především se jednalo o sebehodnotící dotazníky, v nichž dospělí retrospektivně hodnotili vztahy s rodiči v dětství. Další studie zmatení rolí začaly sledovat také rodičovské chování, které pravděpodobně souvisí s narušením hranic rodinného systému. Tímto narušením může být je například rodičovská beznaděj nebo závislé chování (např.: George \& Solomon, 1989; Sroufe, Jacobvitz, Mangelsdorf, DeAngelo, \& Ward, 1985).

Potřeba zkoumat chování rodičů a dětí v rámci narušení rodinného systému i z pohledu rodiče vedla výzkumníky k vytvoření několika metod, které se postupně zdokonalovaly pro potřeby jednotlivých studií.

Experience of Caregiving Interview (ECI, Solomon \& George, 1996) je polostrukturovaný rozhovor upravený Georgeovou a Solomonovou (1996) z původního Aberova rozhovoru Parent Development Interview (PDI, Aber et al. 1985). Ten zjišt'uje rodičovskou reprezentaci afektivních zkušeností se sebou a se svým dítětem. Rozhovor PDI byl různými autory modifikován (např.: Button, Pianta, \& Marvin, 2001; Mayseless, 2006), Mayselessová a Sharfová (2006) přidaly do svého kódovacího systému škálu zmatení rolí (cit dle VuliezCoady a kol. 2013). 
L. Pivodová, P. Daňsová, L. Lacinová: Dotazník zmatení rolí pro adolescenty: Sdělení o vývoji sebeposuzovací metody

Zmíněný ECI je navržen tak, aby vedl rodiče k reflexi událostí, které zažívali se svými dětmi a emocích s těmito událostmi spojenými. Rodiče mají za úkol sami sebe popsat jako rodiče, popsat své zkušenosti a emoční prožívání ve vztahu k jejich dítěti (napřr. radost, pocity viny, hněv). Rodiče mají uvést pět př́davných jmen, která podle nich vystihují jejich vztah $\mathrm{s}$ dítětem a svou volbu zdůvodnit a podložit konkrétními př́íklady. Pozornost je dále věnována situacím, které jsou spojeny s pravděpodobnou aktivací vazby u dítěte (např. separace, vstup do školy).

Pomocí ECI definovala Solomonová, Georgová a De Jongová (1995) rodičovskou bezmoc (parental helplessness) jako důležitý faktor související se zmatením rolí z pohledu rodiče. Solomonová a Georgeová (1996) zjistily, že pocit bezmoci rodiče ve vztahu k dítěti souvisel s kontrolujícím chováním dítěte směrem k rodiči. Tyto výsledky byly replikovány na dalším vzorku matek ze střední tř́́dy a jejich dětí předškolního věku (Solomon \& George, 2006). Na základě těchto studií vyvinuly autorky sebehodnotící dotazník měřící rodičovskou bezmoc pro matky The Caregiving Helplessness Questionaire (CHQ; George \& Solomon, 2011). Dotazník je určen pro matky dětí ve věku 3-11 let. Dvacetišestipoložkový dotazník obsahuje 3 faktory: mateřskou bezmoc (mother helpless), strach matky o dítě (mother - child frightened) a péče o dítě (child caregiving).

Vulliez-Coadyová a Lyonsová-Ruthová (2009) vytvořily kódovací systém, který využívaly pro kódování polostruktorovanýchrozhovorů ECI - The Parental Assessment of Role Confusion Scale (PARC). Rozlišily a popsaly 9 dimenzí zmatení rolí: a) potřeba emocionální podpory od dítěte, b) indikátory sexualizace ve vztahu s dítětem, c) rovnost či obrácení hierarchického vztahu s dítětem, d) rodičovskou bezmoc v interakci s dítětem, e) rodičovská potřeba instrumentální a finanční pomoci, f) obava a ochraňování rodičů dětmi, g) rodiče vyjadřují slabost vůči svému dítěti, h) když se ptáme na dítě, vztahuje výroky na sebe, i) popis agresivního, nepřátelského chování dítěte vůči rodiči. Analýza odpovědí pomocí PARC tedy umožňuje kategorizovat vnímání interakce mezi rodičem a dítětem z pozice rodičů.

Lyons-Ruthová s kolegy vyvinula kódovací systém pro interakci rodiče a dítěte - The Goal Corrected Partnership in Adolescence Coding Systems (GPACS, Lyons-Ruth, Bureau, Riley, \& Atlas-Corbett, 2009). Pomocí něj probíhá kódování nahrávek interakce mezi matkou a dítětem, kdy matka a adolescent byli účastni jedné hodiny rozhovoru a potom následovalo nestrukturované pětiminutové setkání, poté deset minut rozhovoru na téma neshody v jejich vztahu. Metoda zahrnuje jak zjišt’ování zmatení rolí v rámci dyády rodič/adolescent, tak měří trestající a pečující kontrolované chování dětí ke svým rodičům.

Metody na zjišt'ování narušení hranic rodinného systému z pozice rodiče jsou cenné jak pro rozšiřování poznatků, tak při terapeutické práci. Díky nim lze získat komplexnější informace o mechanismu přebírání kompetencí a rolí v rodinném systému. Umožňují také zjistit, do 
L. Pivodová, P. Daňsová, L. Lacinová: Dotazník zmatení rolí pro adolescenty: Sdělení o vývoji sebeposuzovací metody

jaké míry a jakým způsobem se rolí jeden z rodičů vzdává, př́ípadně jak je jeho dítě přebírá a kdo z nich je v této situaci aktivnějším činitelem.

\section{Tvorba dotazníku Zmatení rolí pro adolescenty}

O zachycení fenoménu zmatení rolí/parentifikace pomocí dotazníků či polostrukturovaných rozhovorů se snaží již několik dekád celá řada výzkumníků. Nejčastěji se jedná o dotazníky retrospektivní, jejichž použití má výhodu při kauzálním zjištování důsledků zmatení rolí na psychický vývoj. Dále je využíváno i dotazování rodičů na jejich chování vůči dětem. Zachycení chování parentifikujícího rodiče je významné také pro využití těchto poznatků v poradenství a terapii rodiny.

Naším záměrem je podívat se na problematiku kostruktu zmatení rolí aktuálně z pohledu dospívajícího. Doposud se aktuální změny rolí v rodinném systému zjišt'ovaly pomocí rozhovorů bud' s rodiči, převážně s matkami, nebo se zjišt'ovaly retrospektivně od dětí, které v době dotazování byly již dospělé. V současné době chybí metoda, která by detekovala a rozlišovala zmatení rolí u dětí aktuálně.

Cílem této studie je tvorba dotazníku, který by zachytil míru zmatení rolí tak, jak ji aktuálně prožívají adolescenti. Při tvorbě dotazníku je kladen důraz na jeho srozumitelnost, jednoduchost a pokud možno stručnost při zachování pokrytí různých aspektů fenoménu zmatení rolí. Dotazník aspiruje na nižší počet položek, než tomu bylo u starších metod. Záměrem též je, aby byl vhodný pro celé období adolescence (cca od 11 do 18 let), a také pro dospívající s různou úrovní kognitivních schopností (děti s různou kvalitou pozornosti, schopnosti soustředění, různým stupněm IQ). Dotazník by měl nově také zachytit případné rozdíly v podobě zmatení rolí v jednotlivých dyádách (matka-dcera, matka-syn, otec-dcera, otec-syn). Dosavadní metody (např. Parentification Questionnaire - Adult, Parentification Inventory) měřily zmatení rolí a přebírání kompetencí pouze obecně (např.: "Jednotliví členové rodiny se za mnou chodí svěřovat se svými problémy."). Nástroje tak zatím nijak nezohledňovaly, který z rodičů nebo členů rodiny se dítěti chodí svěřovat se svými problémy, přestože se celá řada výzkumníků domnívá, že nejen míra zmatení rolí, ale také to, v jaké dyádě rodič-dítě se odehrává, má odlišný dopad na ukazatele adaptace a psychického vývoje (např.: Amato \& Afifi, 2006; Macfie, Houts, McElwain, \& Cox, 2005).

Lze tedy předpokládat, že může mít pro dítě či dospívajícího odlišný dopad to, zda se mu svěřuje s problémy otec či matka, ale také to, zda se svěřují synovi či dceři. Na základě výše uvedeného by měl nový nástroj splňovat následující kritéria: 1) mělo by se jednat o percepci rodinné situace dospívajícím, 2) měl by zachycovat aktuální stav a míru zmatení rolí v rodině, 3) měl by být jednoduchý, srozumitelný a krátký při zachování obsahové šíře konceptu zmatení rolí, a 4) měl by zachycovat zmatení rolí ve vztahu k matce a otci odděleně. 
L. Pivodová, P. Daňsová, L. Lacinová: Dotazník zmatení rolí pro adolescenty: Sdělení o vývoji sebeposuzovací metody

Tvorba dotazníku Zmatení rolí pro adolescenty probíhala v několika krocích. Postup tvorby dotazníku je tak dokumentován prostřednictvím tří studií, které na sebe navazují. Na základě výsledků předchozích výzkumů, existujících metod a vlastní kvalitativní studie (viz dále) byly vytvořeny jednotlivé položky, které byly podrobeny kognitivnímu interview s adolescenty. Po úpravě položek byla provedena první pilotáž (studie I). Po analýze byly některé položky změněny. Takto upravený dotazník procházel druhou pilotáží (studie II). Po následné úpravě metody byl dotazník administrován v rámci větší studie (studie III).

\section{Studie I}

\section{Metoda}

\section{Tvorba dotazníku Zmatení rolí pro adolescenty (ZRA): Pilotáž I}

Tvorbě dotazníku předcházela realizace kvalitativní studie Pivodové a Lacinové (2016), která měla za cíl popsat fenomén spousifikace. Spousifikace je jedním z typů zmatení rolí. Byly detekovány tři kategorie, pomocí kterých je možno tento fenomén charakterizovat: typy spousifikace, okolnosti vzniku spousifikace a dítě jako aktér spousifikace - míra jeho aktivního zapojení. Jednotlivé typy spousifikace (Pivodová \& Lacinová, 2016) a položky retrospektivního sebehodnotícího dotazníku Parentification Questionnaire (PQ) Jurkovice a Thirkieda (1998) sloužily jako východisko pro tvorbu položek dotazníku ZRA.

Zjištěných typů spousifikace, které se manifestují v projevech chování a přejímaných kompetencích, bylo popsáno celkem šestnáct (např. starost o chod domácnosti, rodič si jde pro radu). Dotazník PQ je tvořen třiceti položkami, které popisují konkrétní chování v rámci parentifikace. Pro zachování jednoduchosti a nižšího počtu položek byly kategorie, které mají podobný význam sloučeny. Např́íklad ze dvou kategorií typů spousifikace "pomoc $s$ prarodiči” a "pomoc se sourozenci” a zároveň z otázky č. 6 z dotazníku PQ („Byl jsem často zodpovědný za péči o člena rodiny. Např.: umývání, krmení, oblékání, atp.)“a z položky č. $19 \mathrm{z}$ PQ („Často mě rodiče žádali o pomoc se sourozenci“), které mají téměř totožný význam, byla vytvořena nová položka: "Pomáhám rodinným příslušníkům s úkoly, na které nestačí (např. sourozencům $s$ domácími úkoly, babičce s nákupem).” Lze předpokládat, že význam i typ zmatení rolí rolí je natolik podobný, že sloučíme-li osoby (v našem případě sourozenec, babička), kterým dítě pomáhá, bude zachován typ zmatení rolí, který chceme měřit. Jiným příkladem sloučení je kategorie typů spousifikace "financování potřeb rodičü"a "podíl na financování domácnosti". V dotazníku PQ byla použita tato formulace "Pomáhám rodičům zvládnout jejich finanční problémy (např. Nakupuji, platím některé účty).", která dobře reprezentuje námi zjištěné kategorie a byla tedy ponechána $\mathrm{v}$ dotazníku ZRA beze změny. Na základě jednotlivých typů spousifikace a položek z PQ bylo vytvořeno 9 položek (celé znění viz Přílohy č. 1) s instrukcí. Respondenti tyto položky hodnotí na pětibodové Likertově škále (vưbec mne to nevystihuje - úplně mne to vystihuje). 
L. Pivodová, P. Daňsová, L. Lacinová: Dotazník zmatení rolí pro adolescenty: Sdělení o vývoji sebeposuzovací metody

Tato verze dotazníku byla podrobena kognitivnímu interview. Rozhovory, které měly za cíl ověření srozumitelnosti položek, byly realizovány s dvěma jedenáctiletými (raná adolescence) dvěma čtrnáctiletými (střední adolescence) a dvěma sedmnáctiletými adolescenty (pozdní adolescence). Vzniklo tedy šest různých verzí komentářủ a poznámek k již formulovaným položkám, ze kterých była následně vytvořena verze společná. Komentáře a připomínky k položkám se očekávatelně lišily v závislosti na věku adolescentů zcela v souladu s teorií kognitivního vývoje dle Piageta (Piaget \& Inhelderová, 2014). Pro nejmladší adolescenty byly předložené položky př́liš abstraktní a potřebovali více konkrétních příkladů oproti starším adolescentům, které naopak konkrétní příklady spíše rušily. Při revizi formulací jednotlivých položek byl brán zřetel jak na jednotlivé připomínky respondentů, tak na kognitivně-vývojové hledisko. Jednotlivá znění položek se přizpůsobovala převážně těm nejmladším. Položky byly upraveny tak, aby byly co nejvíce obecné (respondenti z pozdní adolescence zmiňovali, že pokud jde o konkrétní formulace, tak se cítí být naváděni do určité formy odpovědi), u většiny z nich je $\mathrm{v}$ závorce uveden př́klad pro lepší srozumitelnost (což byl požadavek respondentů z rané adolescence, kdy obecné formulace pro ně byly příliš abstraktní, a požadovali vysvětlení pomocí konkrétních př́kladů). Např́klad u položky „Máma nebo táta za mnou chodí pro radu ve věcech, o kterých by měli rozhodovat spíše oni sami." respondenti v rámci kognitivního interview zmiňovali její nejasnost a víceznačnost ve formulaci „oni sami“. Tato položka byla tedy přeformulována následovně tak, aby obsahovala jasnou myšlenku, že jde o rozhodování, které př́śluší rodičům př́ípadně jiným dospělým: „Máma nebo táta ode mě chtějí poradit ve věcech, o kterých si myslím, že by se měli radit mezi sebou nebo s jinými dospělými.” U položky: „Často doma uklízím nejen po sobě, ale i po ostatnich (např. po mladším sourozenci, po rodičích).", došlo k obsahovému zpřesnění, rozšíření a uvedení příkladů: „Uklízím doma po sobě, ale i po ostatních (např. po mladším sourozenci, po rodičích), nebo vykonávám domácí práce za ostatní (např. vařím, peru)”. Z položky byl odstraněn kvantifikátor frekvence „často“, který byl pro respondenty matoucí a nejednoznačný. Byly upraveny i slovní kotvy u hodnocení Likertovou škálou na "úplně to na mě sedí - vůbec to na mě nesedî", které se více blíží běžně užívanému jazyku adolescentů než původní verze („vůbec mě to nevystihuje - úplně mě to vystihuje“).

Dotazník s devíti sebehodnotícími položkami prošel první pilotáží. Položky v Pilotáži I byly označeny písmeny v abecedě, aby byly odlišeny od následné Pilotáže II (viz níže), kde jsou položky přeformulované a jsou očíslovány. Cílem pilotáže bylo ověření vnitřní konzistence a faktorové př́íslušnosti položek.

\section{Výzkumný postup}

Pilotáž proběhla v ř́jjnu 2016 na gymnáziu na severní Moravě. Účastnilo se jí 58 respondentů ze šestiletého gymnázia, respondenti byli ve věku 13-17 let. Proces výběru vzorku byl podmíněn souhlasem ředitele gymnázia s účastí studentů školy ve výzkumu, dále byly vybrány tř́ídy, jejichž žáci korespondovali s požadovaným věkem účastníků. $V$ těchto třídách 
L. Pivodová, P. Daňsová, L. Lacinová: Dotazník zmatení rolí pro adolescenty: Sdělení o vývoji sebeposuzovací metody

byli studenti s výzkumem seznámeni. Studentům, kteří souhlasili se svou účastí na výzkumu, byl předán formulář pro udělení informovaného souhlasu rodičů. Výzkum byl realizován jako anonymní a získané odpovědi byly uchovávány na zabezpečeném místě. Dotazníky byly administrovány ve verzi tužka - papír (celé znění dotaníku viz Přílohy č. 2).

\section{Výsledky: Pilotáž I}

Z celkového počtu 58 zůčastněných vyplnilo dotazník zmatení rolí 56 respondentů ve věku 13-17 let, $M=15,02$ (SD=1,8), z toho 65,5\% dívky, 35, 5\% chlapci. Analýza položek byla provedena v programu SPSS 22. Popisné statistiky jednotlivých položek jsou uvedeny v následující tabulce 1.

TABULKA 1

Popisné statistiky jednotlivých položek v první verzi dotazníku

\begin{tabular}{|c|c|c|c|c|c|c|c|c|}
\hline & $N$ & $M$ & $S D$ & $\begin{array}{l}\min - \\
\max \end{array}$ & šikmost & špičatost & $r_{k s}$ & $\begin{array}{c}\alpha \text { bez } \\
\text { položky }\end{array}$ \\
\hline $\begin{array}{l}\text { A_Stává se, že když s něčím } \\
\text { doma pomůžu, nikdo si toho ani } \\
\text { nevšimne. }\end{array}$ & 56 & 3,13 & 1,35 & $1-5$ & $-0,33$ & $-1,16$ & $-0,08$ & 0,726 \\
\hline $\begin{array}{l}\text { B_Máma nebo táta se mě chodí } \\
\text { svěřovat se svými starostmi. }\end{array}$ & 56 & 3,41 & 1,32 & $1-5$ & $-0,47$ & $-0,81$ & 0,36 & 0,631 \\
\hline $\begin{array}{l}\text { C_Máma nebo táta ode mě } \\
\text { chtějí poradit ve věcech, o } \\
\text { kterých si myslím, že by se měli } \\
\text { radit mezi sebou nebo s jinými } \\
\text { dospělými. }\end{array}$ & 54 & 3,85 & 1,17 & $1-5$ & $-0,72$ & $-0,43$ & 0,43 & 0,616 \\
\hline $\begin{array}{l}\text { D_Pokud mámu nebo tátu něco } \\
\text { trápí, utěšuji ji/ho. }\end{array}$ & 56 & 2,86 & 1,41 & $1-5$ & 0,06 & $-1,34$ & 0,43 & 0,615 \\
\hline $\begin{array}{l}\text { E_Chodím sám/sama nakupovat } \\
\text { pro celou rodinu. }\end{array}$ & 56 & 4,14 & ,98 & $2-5$ & $-0,66$ & $-0,93$ & 0,24 & 0,66 \\
\hline $\begin{array}{l}\text { F_Někdy vypomáhám rodičům s } \\
\text { penězi (např. nakoupím ze svých } \\
\text { úspor, peníze rodičům půjčím). }\end{array}$ & 56 & 3,86 & 1,29 & $1-5$ & $-0,74$ & $-0,69$ & 0,30 & 0,644 \\
\hline $\begin{array}{l}\text { G_Pomáhám rodinným } \\
\text { příslušníkům s úkoly, na které } \\
\text { nestačí (např. sourozencům s } \\
\text { domácími úkoly, babičce s } \\
\text { nákupem, mámě se žehlením). }\end{array}$ & 56 & 2,34 & 1,21 & $1-5$ & 0,78 & $-0,07$ & 0,40 & 0,624 \\
\hline $\begin{array}{l}\text { H_Bývám zodpovědný za péči o } \\
\text { člena rodiny (např. umývání, } \\
\text { krmení, oblékání sourozence, } \\
\text { pomoc nemocným rodičům či } \\
\text { prarodičům). }\end{array}$ & 56 & 3,12 & 1,45 & $1-5$ & $-0,04$ & $-1,42$ & 0,59 & 0,571 \\
\hline $\begin{array}{l}\text { I_Uklízím doma po sobě, ale i po } \\
\text { ostatních (např. po mladším }\end{array}$ & 56 & 2,82 & 1,19 & $1-5$ & 0,26 & $-0,69$ & 0,45 & 0,613 \\
\hline
\end{tabular}


L. Pivodová, P. Daňsová, L. Lacinová: Dotazník zmatení rolí pro adolescenty: Sdělení o vývoji sebeposuzovací metody

sourozenci, po rodičích), nebo

vykonávám domácí práce za

ostatní (např. vařím, peru).

Poznámka. rks - korigovaná korelace položky se škálou

Následně byla provedena explorační faktorová analýza pro dva faktory emocionální zmatení rolí (EZR) instrumentální zmatení rolí (IZR). Pomocí výpočtu faktorových zátěží bylo zjišt'ováno, do jaké míry je faktor položkou sycen. Pro EZR to splňovaly položky B, C, D, a pro instrumentální IZR to splňovaly položky F, G, H a I viz tab č. 2. položka E („,Chodím sám/sama nakupovat pro celou rodinu“.) nesytila ani jeden z faktorů.

Pro explorační faktorovou analýzu byla použita metoda extrakce metoda nejmenších čtverců (ordinary least square) s šikmou rotací (direct oblimin).

\section{TABULKA 2}

Faktorové zátěže Pattern Martix po rotaci direct oblimin

\begin{tabular}{l|c|c}
\hline \multirow{2}{*}{} & \multicolumn{2}{|c}{ Faktory } \\
\cline { 2 - 3 } A (EZR) & 1 & 2 \\
\cline { 2 - 3 } B (EZR) & 0,119 & 0,293 \\
C (EZR) & 0,127 & $-\mathbf{0 , 9 2 4}$ \\
D (EZR) & 0,241 & $-\mathbf{0 , 3 2 1}$ \\
\hline E (IZR) & 0,366 & $-0,505$ \\
F (IZR) & 0,214 & $-0,034$ \\
G (IZR) & $\mathbf{0 , 5 1 1}$ & $-0,083$ \\
H (IZR) & $\mathbf{0 , 5 7 0}$ & $-0,057$ \\
I (IZR) & $\mathbf{0 , 8 3 6}$ & $-0,048$ \\
\hline
\end{tabular}

Poznámka: EZR je zkratkou pro emocionální zmatení rolí, IZR je zkratkou pro instrumentální zmatení rolí

Ze získaných hodnot faktorové analýzy mohla být provedana Pearsonova korelace mezi faktory EZR a IZR. Faktory spolu korelují, hodnota korelace je -0,247 a korelují spolu i součtové skóry. Součtové skóry položek náležících do jednotlivých faktorů mají hodnotu korelace 0,352 , korelace je signifikantní $(p=0,009)$. $Z$ korelace je patrné, že čím vyšší je míra instrumentální parentifikace, tím je vyšší i míra emocionální parentifikace. Tyto faktory jsou na sobě závislé. Dotazník je po první pilotáži dvoufaktorový. Faktor emocionální zmatení rolí obsahuje tři položky, faktor instrumentální zmatení rolí obsahuje čtyři položky. Tyto faktory spolu korelují.

\section{Diskuze}


L. Pivodová, P. Daňsová, L. Lacinová: Dotazník zmatení rolí pro adolescenty: Sdělení o vývoji sebeposuzovací metody

Výsledky první pilotáže ukazují na dvoufaktorové řešení. Jedná se o faktor instrumentální zmatení rolí, který zahrnuje instrumentální podporu rodiče/ů (např. domácí práce, zacházení s finančními prostředky rodiny) a faktor emocionálního zmatení rolí, který zahrnuje emocionální podporu rodiče/ů (např.: reagování na emoční potřeby rodiče) podobně jako u Hooperové (2007), která rozlišovala instrumentální a emocionální parentifikaci. V souladu s aktuálními zjištění výzkumníků (Macafie, Brumariu, \& Lyons-Ruth, 2015; Vulliez-Coady, Solheim, Nahum, \& Lyons-Ruth, 2016) jsme se přiklonili k užívání termínu zmatení rolí. Domníváme se, že oproti dříve používané parentifikaci termín zmatení rolí přesněji vystihuje různou intenzitu opuštění rodičovské role matky nebo otce a nahrazování této role $\mathrm{v}$ různé míře jeho dítětem. Na základě analýzy byly z dotazníku vyřazeny dvě položky. Položka A ("Stává se, že když s něčím doma pomůžu, nikdo si toho ani nevšimne.”) zřejmě významově neodpovídá fenoménu zmatení rolí a pravděpodobně spíše může souviset se sebehodnocením dospívajících. Položka E („Chodím sám/sama nakupovat pro celou rodinu“.) byla formulovana se záměrem zachytit zodpovědnost adolescenta za chod domácnosti a starosti o finanční záležitosti rodiny. V této podobě však položka neodkazuje na zmatení rolí, ale spíše na situaci, kdy se dítě učí postupně samostatně nakupovat. Jedná se o získávání kompetencí v rámci tzv. finanční gramotnosti, které jsou pro období adolescence vývojově zcela adekvátní. Faktor emocionálního zmatení rolí sytí zbylé tři položky (B, C, D) a faktor instrumentální zmatení rolí sytí čtyři položky (F, G, H, I). Aby nebyl fenomén zmatení rolí obsahově zúžen, v dalším kroku bylo nutné doplnění dalších položek a přeformulování položek, které byly vyřazeny tak, aby pokrývaly obsahově ty aspekty zmatení rolí, které má dotazník zachytit. Oba faktory tak byly v následném kroku rozšířeny o další nové položky tak, aby vystihovaly tyto dva aspekty zmatení rolí v rodině co nejšířeji. Jedním z našich cílů bylo také specifikovat odlišení otce a matky v kontextu zmatení rolí, což v následném kroku znamenalo, že položky emocionálního zmatení rolí byly formulovány jak pro hodnocení chování otce, tak pro chování matky odděleně.

\section{Studie II}

\section{Metoda}

\section{Doplnění položek do jednotlivých faktorů}

Faktor instrumentální zmatení rolí po první pilotáži obsahoval tři položky. Tento počet není z hlediska reliability a z hlediska popisu fenoménu v celé jeho šíři vyhovující. Snažili jsme se tedy opět probrat původní kategorie jednotlivých projevů a doplnit tuto každou kategorii o dvě položky. Faktor instrumentální zmatení rolí byl doplněn o tvrzení "Často mám pocit, že se rodina bez mé pomoci nemůže obejít." Jedná se o přeformulovanou položku A, která była na základě pilotáže I vyřazena. Doplněná položka instrumentální parentifikace zastupuje dosud chybějící kategorii přebírání zodpovědnosti: “Nastávají situace, kdy přebírám za rodiče 
L. Pivodová, P. Daňsová, L. Lacinová: Dotazník zmatení rolí pro adolescenty: Sdělení o vývoji sebeposuzovací metody

zodpovědnost (např. vyřizuji za rodiče platby za domácnost, pomáhám jim vjejich zaměstnání).“.

U faktoru emocionální zmatení rolí, který po první pilotáži obsahoval čtyři položky, jsme se snažili doplnit položku, která by charakterizovala a nejlépe vystihovala situace, kdy se rodič chová $\mathrm{k}$ dítěti partnersky (child as a spouse): "Když mámě táta chybí, nahrazuje jeho př́tomnost mnou (např. díváme se spolu na filmy, které se líbí mámě, obejme mě, když je jí smutno)." nebo" Když tátovi máma chybí, nahrazuje její přítomnost mojí (např. díváme se spolu na filmy, které se líbí tátovi, obejme mě, když je mu smutno.).” Důvody k doplnění této položky vycházely z naší předchozí studie (Pivodová \& Lacinová, 2016) a ze zjištění Vulliezové a kolektivu (2016). Oba výzkumy považují formu spousifikace za jednu z podstatných podob emocionální zmatení rolí, kde je oslaben či mizí protektivní faktor rodiče ke svému dítěti. Dítě je v tuto chvíli vnímáno rodičem jako pečující partner.

\section{Rozdělení faktoru emocionální zmatení rolí na emocionální zmatení rolí ze strany matky a emocionální zmatení rolí ze strany otce}

Jak již bylo zmíněno, emocionální zmatení rolí (Jurkovic \& Thirkield, 1998) bylo doposud zachycováno $\mathrm{v}$ jednotlivých měřících nástrojích bez ohledu na to, zda se daného chování dopouští matka či otec. $\mathrm{V}$ již zmiňované metodě PQ jsou položky postihující emocionální zmatení rolí formulovány například následovně „Rodiče se snaží dostat mě v konfliktu na svou stranu.”, nebo „Jednotliví členové rodiny si ke mně chodí pro radu se svými problémy.”

Z výzkumů, které zjišt'ovaly dopad zmatení roli na aspekty jednotlivé vývoje dítěte (Katz, Petracca, \& Rabinowitz, 2009; Mayseless, Bartholomew, Henderson, \& Trinke, 2004; Shier, Herke, Nickel, Elge, \& Hardt, 2015), vyplývá, že je ale důležité rozlišovat, u kterého z rodičů dochází $\mathrm{k}$ narušování hranic rodinného systému nebo tedy u kterého z nich dochází ve vztahu s dítětem k zmatení rolí. Emocionální zmatení rolí je tak v nově vytvářené metodě ZRA měřeno stejnými položkami, jak pro matku, tak pro otce, jejchž chování adolescent posuzuje (viz Příloha č. 3). Položky byly pro druhou pilotáž označeny čísly 1-16.

\section{Výsledky: Pilotáž II}

Pilotáž druhé verze dotazníku (navazuje na výsledky z Pilotáže I) byla administrovaná účastníkům kohortového longitudinálního výzkumu Všichni moji blízcí (Vývoj vztahů v adolescenci: Využití perspektivy citové vazby, dynamicko-systémového př́stupu a metody časových řad -GA16-03059S), pod záštitou Institutu výzkumu dětí, mládeže a rodiny při Fakultě sociálních studií Masarykovy univerzity v Brně a s přispěním Grantové agentury České republiky. Sběr dat začal v září 2016 a trval do roku 2018. Účastníky byli studenti víceletých gymnázií v Brně a Žd'áru nad Sázavou, ve věkovém rozpětí 11 až 19 let. Hlavním cílem longitudinálního projektu bylo zachytit vývoj a změny ve vazbové hierarchii v tomto období lidského života. Administrace dotazníku byla administrována v lednu 2017 on-line 
L. Pivodová, P. Daňsová, L. Lacinová: Dotazník zmatení rolí pro adolescenty: Sdělení o vývoji sebeposuzovací metody

formou. Tento způsob administrace poskytuje větší soukromí k vyplňování citlivých otázek, které dotazník zmatení rolí obsahuje, na druhou stranu za nevýhodu lze pokládat nižší návratnost.

Z 214 participantů projektu Všichni moji blízcí vyplnilo dotazník ZRA 154 z nich. Průměrný věk adolescentů zahrnutých do analýzy je 15,23 (SD =2,02). Nejnižší věk byl 12 let a nejvyšší 19 let. Dívky tvořily $61,7 \%(N=95)$ a chlapci 38,3 \% $(N=59)$ výzkumného souboru.

Byla provedena položková analýza a následně také konfirmační faktorová analýza. Podle výsledků položkové analýzy (viz tab. č. 3) dvě z původních šestnácti položek (č. 6 a 13) nejsou pro škálu vhodné, protože mají slabé korigované korelace se skóre škály, a tedy nerozlišují dobře mezi různými úrovněmi zmatení rolí. U položky č. 6 („Někdy vypomáhám rodičům s penězi. ") je třeba mít na paměti také specifika vzorku. V tomto případě se jednalo o studenty víceletých gymnázií, je tedy možné, že daná položka není vhodná pro tuto populaci. Je možné, že u dětí ze základních škol, popř. u dětí z rodin s nižším socioekonomickým statusem, by položka pro škálu vhodná byla. Druhou vyřazenou položkou je položka 13 („Máma o mně ř́ká, že jsem stejný/stejná jako táta. '), která nekoreluje s ostatními položkami škály emoční parentifikace pro matku, ačkoli stejná položka pro otce je do škály emoční parentifikace otce vhodná. Zdá se tedy, že matky, ne však otcové, říkají dítěti, že je jako otec, bez ohledu na míru zmatení rolí v rodině. Popisné statistiky pro položky i pro jednotlivé subškály jsou uvedeny v tabulce č. 3.

\section{TABULKA 3}

Popisné statistiky pro Dotazník zmatení rolí

\begin{tabular}{|c|c|c|c|c|c|c|c|c|}
\hline & $N$ & $M$ & $S D$ & $\begin{array}{l}\min - \\
\max \end{array}$ & šikmost & špičatost & $r_{k s}$ & $\begin{array}{c}\alpha \text { bez } \\
\text { položky }\end{array}$ \\
\hline \multicolumn{9}{|l|}{ Instrumentální zmatení rolí } \\
\hline $\begin{array}{l}\text { 1_Pomáhám rodinným } \\
\text { príslušníkủm s úkoly, na které } \\
\text { nestačí. }\end{array}$ & 154 & 3.20 & 0.97 & $1-5$ & 0.16 & -0.53 & 0.57 & 0.580 \\
\hline $\begin{array}{l}\text { 2_Uklízím po sobè, ale i po } \\
\text { ostatních nebo vykonávám } \\
\text { domácí práce za ostatní. }\end{array}$ & 154 & 2.96 & 1.06 & $1-5$ & 0.06 & -0.47 & 0.40 & 0.631 \\
\hline $\begin{array}{l}\text { 3_Bývám zodpovědný za péči o } \\
\text { člena rodiny. }\end{array}$ & 153 & 2.69 & 1.28 & $1-5$ & 0.17 & -1.13 & 0.43 & 0.624 \\
\hline $\begin{array}{l}\text { 4_Často mám pocit, že se rodina } \\
\text { bez mé pomoci nemǔže obejít. }\end{array}$ & 154 & 1.88 & 1.01 & $1-5$ & 1.14 & 0.88 & 0.45 & 0.616 \\
\hline $\begin{array}{l}\text { 5_Nastávají situace, kdy } \\
\text { přebírám za rodiče } \\
\text { zodpovědnost. }\end{array}$ & 154 & 1.66 & 0.90 & $1-4$ & 1.20 & 0.46 & 0.43 & 0.625 \\
\hline $\begin{array}{l}\text { 6_Někdy vypomáhám rodičǔm s } \\
\text { penězi. }\end{array}$ & 154 & 2.03 & 1.17 & $1-5$ & 0.93 & -0.02 & 0.20 & 0.703 \\
\hline
\end{tabular}


L. Pivodová, P. Daňsová, L. Lacinová: Dotazník zmatení rolí pro adolescenty: Sdělení o vývoji sebeposuzovací metody

\begin{tabular}{|c|c|c|c|c|c|c|c|c|}
\hline \multicolumn{9}{|l|}{ Emoční zmatení rolí - matka } \\
\hline $\begin{array}{l}\text { 7_Máma ode mě chce poradit ve } \\
\text { věcech, o kterých si myslím, že } \\
\text { by se měla radit s tátou, nebo s } \\
\text { jinými dospělými. }\end{array}$ & 152 & 1.81 & 0.86 & $1-4$ & 0.76 & -0.29 & 0.48 & 0.583 \\
\hline $\begin{array}{l}\text { 9_Máma se mně chodí svěrovat } \\
\text { se svými starostmi. }\end{array}$ & 152 & 2.25 & 1.20 & $1-5$ & 0.55 & -0.92 & 0.58 & 0.509 \\
\hline $\begin{array}{l}\text { 11_Pokud mámu něco trápí, } \\
\text { utěšuji ji. }\end{array}$ & 152 & 2.81 & 1.28 & $1-5$ & 0.10 & -1.06 & 0.55 & 0.518 \\
\hline $\begin{array}{l}\text { 13_Máma mně říká, že jsem } \\
\text { stejný/stejná jako táta. }\end{array}$ & 152 & 2.74 & 1.44 & $1-5$ & 0.17 & -1.31 & 0.08 & 0.770 \\
\hline $\begin{array}{l}\text { 15_Když mámě táta chybí, } \\
\text { nahrazuje jeho př́tomnost mojí. }\end{array}$ & 150 & 2.03 & 1.18 & $1-5$ & 1.01 & 0.13 & 0.49 & 0.558 \\
\hline \multicolumn{9}{|l|}{ Emoční zmatení rolí - otec } \\
\hline $\begin{array}{l}\mathbf{8} \text { _Táta ode mě chce poradit ve } \\
\text { věcech, o kterých si myslím, že } \\
\text { by se měl radit s mámou, nebo s } \\
\text { jinými dospělými. }\end{array}$ & 152 & 1.53 & 0.77 & $1-4$ & 1.42 & 1.36 & 0.46 & 0.696 \\
\hline $\begin{array}{l}\text { 10_Táta se mně chodí svěřovat } \\
\text { se svými starostmi. }\end{array}$ & 152 & 1.57 & 0.88 & $1-5$ & 1.87 & 3.80 & 0.65 & 0.632 \\
\hline $\begin{array}{l}\text { 12_Pokud tátu něco trápí, } \\
\text { utěšuji ho. }\end{array}$ & 151 & 2.23 & 1.23 & $1-5$ & 0.67 & -0.61 & 0.47 & 0.694 \\
\hline $\begin{array}{l}\text { 14_Táta mně říká, že jsem } \\
\text { stejný/stejná jako máma. }\end{array}$ & 151 & 2.15 & 1.21 & $1-5$ & 0.80 & -0.34 & 0.39 & 0.728 \\
\hline $\begin{array}{l}\text { 16_Když tátovi máma chybí, } \\
\text { nahrazuje její přítomnost mojí. }\end{array}$ & 152 & 1.77 & 1.05 & $1-5$ & 1.44 & 1.50 & 0.55 & 0.655 \\
\hline
\end{tabular}

Poznámka. rks - korigovaná korelace položky se škálou

Pro ověření faktorové struktury byla použita konfirmační faktorová analýza s odhadem WLSMV (mean- and variance-adjusted weighted least squares) pro ordinální data v programu Mplus. Byl testován tř́faktorový model s 5 položkami instrumentálního zmatení rolí, 4 položkami emočního zmatení rolí k matce a 5 položkami emočního zmatení rolí k otci. Tento model vykazoval slabou shodu s daty $\left(\chi^{2}(74)=248.420, \mathrm{p}<0.001 ;\right.$ CFI $=0.847$; RMSEA $=$ 0.112; WRMR $=1.251$ ), bylo tedy přistoupeno $\mathrm{k}$ respecifikaci modelu. Na základě modifikačních indexů bylo patrné, že položky ze škál emočního zmatení rolí pro matku a otce, které mají shodné znění pouze s tím rozdílem, zda se týkají právě matky nebo otce, sdílí navíc rozptyl, který není možné vysvětlit jejich př́slušností do škál. Vzhledem $\mathrm{k}$ jejich obsahové podobnosti a k tomu, že následovaly ve škále při administraci hned po sobě, byl model respecifikován tak, aby rezidua těchto položek mohla korelovat. Shoda tohoto modelu $s$ daty je již poměrně uspokojivá $\left(\chi^{2}(70)=146.436, p<0.001\right.$; CFI $=0.945$; RMSEA $=0.084$; 
L. Pivodová, P. Daňsová, L. Lacinová: Dotazník zmatení rolí pro adolescenty: Sdělení o vývoji sebeposuzovací metody

WRMR=0.925) a model tedy můžeme považovat za pravděpodobně datům odpovídající. Faktorové náboje ve standardizovaném řešení ukazuje obrázek 2 .

\section{OBRÁZEK 2}

Faktorové řě̌ení Dotazníku zmatení rolí ve standardizované podobě

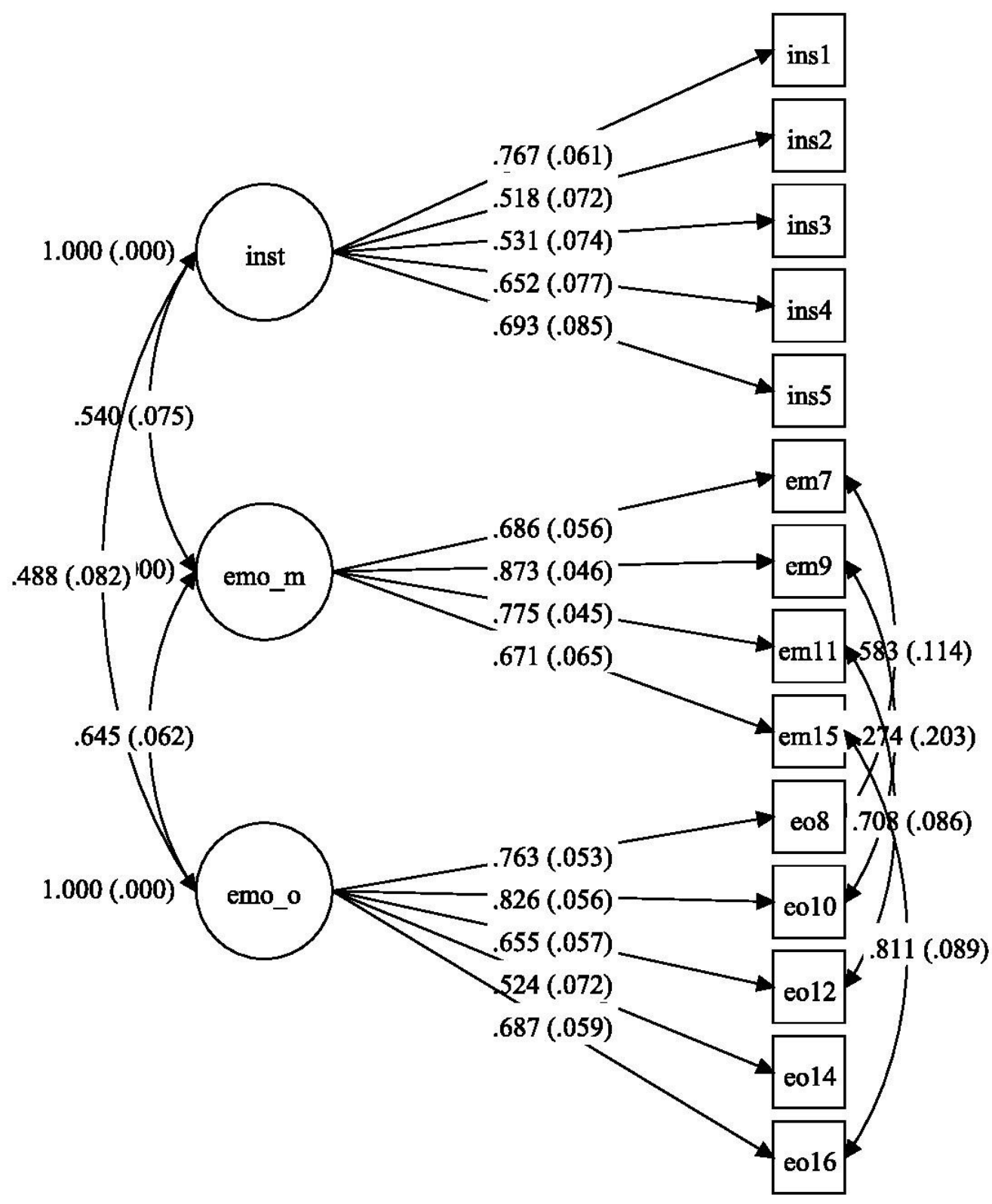

Vnitřní konzistence všech faktorů je uspokojivá (instrumentální zmatení rolí: $\alpha=0.703$, emoční zmatení rolí - matka: $\alpha=0.770$, emoční zmatení rolí - otec: $\alpha=0.728$ ). Součtové skóry 
L. Pivodová, P. Daňsová, L. Lacinová: Dotazník zmatení rolí pro adolescenty: Sdělení o vývoji sebeposuzovací metody

jednotlivých faktorů spolu středně silně korelují v očekávaném směru (instrumentální a emoční-matka: $r=0.33$; instrumentální a emoční-otec: $r=0.41$; emoční-matka a emočníotec: $r=0.56)$.

\section{Diskuze II}

Dotazník zmatení rolí po druhé pilotáži rozlišuje tři faktory - instrumentální zmatení rolí s šesti položkami, emocionální zmatení rolí v dyádě matka - dítě a v dyádě otec - dítě po pěti položkách. Dotazník splňuje požadavek jednoduchosti, je tvořen 16 položkami, z toho pět jich je stejných pro matku a otce. Dotazník je určen pro adolescenty ve věku 11-18 let a zmatení rolí měří aktuálně a z pohledu dítěte.

Je nutné dále řešit několik problémů, které po druhé pilotáži vzešly z analýzy. Faktorové zátěže v I a ve II pilotáži se u položky F a č. 6, které jsou identické („Někdy vypomáhám rodičům s penězi (např:: nakoupím ze svých úspor, peníze rodičům půjčím)."), výrazně lišily. Předpokládáme, že tento rozdíl mohl být způsoben odlišností obou zkoumaných souborů. V první pilotáži byl vzorek z Ostravska, a ve druhé z Brna. Je možné, že socioekonomické podmínky rodin zapojených do výzkumu se mohly v souvislosti s charakterem kraje lišit a význam této položky pro respondenty tak nebyl úplně totožný. $\mathrm{V}$ předcházejícím kvalitativním výzkumu (Pivodová \& Lacinová, 2016) bylo respondenty časté pomáhání s rodinným rozpočtem rodičů zmiňováno. Tento výzkum probíhal s respondenty, kteří byli klienty středisek výchovné péče. Rodiny respondentů spíše patřily k sociálně slabším a typicky se také jednalo o rodiny neúplné. První verze dotazníku byla ověřována sice se studenty gymnázií, nicméně v ostravském kraji, kde lze předpokládat vyšší výskyt sociálně slabších rodin. Pilotáž druhé verze dotazníku probíhala na gymnáziích v Brně a Žd'áru nad Sázavou, kde velká většina adolescentů pocházela z úplných rodin převážně vysokoškolsky vzdělaných rodičů. Lze tedy předpokládat, že finanční situace nepředstavuje pro tyto rodiny existenciální problém, který by se mohl projevit i v zapojování adolescentů do jeho řešení. Ačkoli položka č. 6 má slabé korigované skóre položky, v dotazníku bude zachována. Pokládáme ji za potřebnou, aby podobně jako u dotazníku Jurkovice a Thirkieda (1998) položka byla zachycena i př́padná spoluúčast adolescenta na finančním chodu domácnosti jako jeden z možných projevů instrumentálního zmatení rolí.

Za nevyhovující lze na základě výsledků považovat pořadí položek se stejným zněním pro otce a matku př́mo po sobě. Předpokládáme, že je pro respondenta jednodušší a lépe představitelné popisovat chování jednoho rodiče vcelku (mámy zvlášt' a táty zvlášt'), a nikoliv srovnáváním chování mámy a táty položku po položce. U stejně znějící položky pro matku (13) a otce (14) byla rozdílná korigovaná korelace položky se škálou. U položky 13 („Máma o mně ř́ká, že jsem stejný/stejná jako táta.") byla hodnota $\mathrm{r}_{\mathrm{ks}} 0,08$, což znamená, že tato položka nesytí faktor emocionálního zmatení rolí ze strany matky, oproti položce 14 („Táta o mě ríḱá, že jsem stejný/stejná jako máma."), kde r $\mathrm{ks}_{\mathrm{ks}}$ měla hodnotu 0,39, tzn., že tato 
L. Pivodová, P. Daňsová, L. Lacinová: Dotazník zmatení rolí pro adolescenty: Sdělení o vývoji sebeposuzovací metody

položka sytí faktor zmatení rolí ze strany otce. Je to pravděpodobně dáno tím, že formulace této položky má u každého z rodičů jiný význam. Pro dospívající nemusí být natolik důležité, co říká matka o otci, ale je pro ně důležitější, co říká otec o matce v kontextu zmatení rolí.

Limitující je opět charakter výzkumného souboru, který byl tvořen studenty víceletých gymnázií. Lze předpokládat, že rodinné zázemí studentů gymnázií je např. z hlediska finančního zajištění spíše nadprůměrné (pouze 1,5\% rodičů uvedlo, že jejich výdaje nestačí, aby pokryly všechny jejich výdaje), dále pak míra rozvodovosti je oproti obecné populaci nižší (pouze 17\% rodičů spolu nežije z důvodu rozvodu či rozchodu). Ve vztahu ke klíčové otázce zmatení rolí je pak možné spekulovat, že míra tohoto fenoménu bude v takovém souboru spíše nižší a bude se vyskytovat méně často, než je tomu v obecné populaci. Pro další úpravy dotazníku a jeho definitivní podobu tak bude nutné zahrnout do výzkumů i populaci studentů odborných středních škol a učilišt'.

\section{Studie III}

\section{Metoda}

Dotazník zmatení rolí pro adolescenty byl administrován v rámci rozsáhlejšího výzkumu v baterii spolu s dalšími metodami. Cílem studie bylo ověření dotazníku ZRA u respondentů, kteří by se oproti studentů víceletých gymnázií z hlediska rodinného prostředí více blížili průměru obecné populace.

\section{Úprava formy dotazníku po pilotáži ze studie II}

Dotazník je tvořen třemi subškálami. Instrumentální zmatení rolí (IZR) měří šest položek, které popisují činnosti, které dítě vykonává za rodiče v rodině (např. „Uklízím po sobě, ale $i$ po ostatních - např. po mladším sourozenci, po rodičích, nebo vykonávám domácí práce za ostatní - např. vařím, peru."). Emocionální zmatení rolí v dyádě matka - dítě (EZRm) zachycují pět položek a v dyádě otec - dítě (EZRo) je to také pět položek. Položky emocionální zmatení popisují emoční přebírání rolí za rodiče, které dítě hodnotí pro každého rodiče zvlášt' (např. „Máma/táta se mně chodí svěřovat se svými starostmi."). Adolescenti odpovídají na pětibodové škále od 1 „úplně to na mě sedí" po 5 „vưbec to na mě nesedí". Po pilotáži ve studii II se při explorační a konfirmační analýze dotazníku ZRA objevila problematická místa. Protože obsahově podobné položky pro matku a otce byly ve druhé pilotáži dotazníku administrovány po sobě a sdílely rozptyl, který nebyl možný vysvětlit jejich příslušností do škál, bylo ve studii III při administraci změněno pořadí položek, kdy byly položky s otázkami na matku a otce odděleny položkami na instrumentální zmatení rolí (administrovaná podoba dotazníku ZRA s pořadím položek viz Př́loha 4). Jelikož po pilotáži ze studie II byly problematické položky 6,13 , byla provedena na našem vzorku znovu konfirmační faktorová analýza. 
L. Pivodová, P. Daňsová, L. Lacinová: Dotazník zmatení rolí pro adolescenty: Sdělení o vývoji sebeposuzovací metody

\section{Výzkumný soubor}

Výzkumný soubor adolescentů tvoří studenti 1. a 2. ročníků středních škol s maturitou a středních odborných učilišt'. Studenti byli ve věku 15-21 let. Čtyři z nich již tedy nespadali do období adolescence, nicméně byli do studie zařazeni. Navštěvovali první dva ročníky a žili ve společné domácnosti alespoň s jedním z rodičů. Jednalo se o žáky sedmnácti stř̌edních škol z menších měst, které mají cca do 35 tisíc obyvatel z Moravskoslezského, Olomouckého, Jihomoravského, Zlínského kraje a kraje Vysočina. Proces sběru dat probíhal od října do prosince roku 2019. Z celkového počtu 315 vyplněných dotazníků bylo zařazeno do analýz 293 z nich. Vyřazeno bylo 18 respondentů z důvodu vyplnění dotazníkové baterie pod 10 minut, což byl předem určený limit, který byl stanoven po pilotáži celé testové bateri určenou pro tuto studii. Za tuto dobu nebylo možné dotazník vyplnit, pokud jej respondent přečte. Další 4 respondenti byli vyřazení z důvodu nedostatečného vyplnění dotazníku. Z celkového počtu respondentů zahrnutých do analýz bylo 198 dívek (67,6 \%) a 95 chlapců (32, $4 \%)$. Průměrný věk byl 16,23 let. Skoro polovina respondentů $(46,8)$ byla ve věku 16 let (viz tab č. 4).

TABULKA 4

Rozložení výzkumného souboru adolescentů dle věku a pohlaví

\begin{tabular}{l|ll|ll|ll}
\multirow{2}{*}{ Vĕk } & Dívky & & \multicolumn{2}{|l|}{ Chlapci } & \multicolumn{2}{l}{ Celkem } \\
\cline { 2 - 7 } & $\mathbf{N}$ & $\%$ & $\mathbf{N}$ & $\%$ & $\mathbf{N}$ & $\%$ \\
\hline 15 & 45 & 22,7 & 21 & 22,1 & 66 & 22,5 \\
16 & 105 & 53 & 32 & 33,7 & 137 & 46,8 \\
17 & 44 & 22,2 & 23 & 24,2 & 67 & 22,9 \\
18 & 3 & 1,5 & 4 & 4,2 & 7 & 2,4 \\
19 & 1 & 0,5 & 10 & 10,5 & 11 & 3,8 \\
20 & 0 & 0 & 2 & 2,1 & 2 & 0,7 \\
21 & 0 & 0 & 2 & 2,1 & 2 & 0,7 \\
Nevyplněno & 0 & 0 & 1 & 1,1 & 1 & 0,3 \\
\hline Celkem & 198 & 100 & 95 & 100 & 293 & 100
\end{tabular}

\section{Demografické údaje}

Z celkového počtu 293 adolescentů účastnící se studie bylo 188 adolescentů (tedy 64,6 \%) z úplných rodin (žijí ve společné domácnosti s matkou a otcem). Druhým nejčastějším soužitím bylo v $24,1 \%$ (71 respondentů) soužití s matkou bud' $z$ důvodu rozvodu či rozchodu rodičů. $\mathrm{V}$ nízkých procentech př́ípadů žili respondenti s otcem, ve střídavé péči nebo s pěstouny. Respondenti byli převážně ze dvou sourozenců (52 \%), jedináčkủ bylo 21 \% a 16 
L. Pivodová, P. Daňsová, L. Lacinová: Dotazník zmatení rolí pro adolescenty: Sdělení o vývoji sebeposuzovací metody

$\%$ z nich bylo ze tří sourozenců. Zjišt'ovali jsme nejvyšší dosažené vzdělání rodičů respondentů. Nejčastějším dosaženým vzděláním u matek bylo ve 43,5 \% vzdělání střední s maturitou, u otců v 50,9 \% vzdělání střední bez maturity. Při subjektivním hodnocení finanční spokojenosti hodnotili rodiče své příjmy průměrně. Na škále od 1 do 10 , kde 1 znamená, že patří ve společnosti k velmi chudým a 10 znamená, že patří do společnosti k velmi bohatým, se 40,5 \% označilo uprostřed na čísle 5 a druhým nejčetnějším stupněm (číslem 6) 23,8 \%. Zároveň 60,5 \% rodičů uvedlo, že příjem domácnosti pokrývá všechny výdaje a nedělá jim to problém, 32 \% rodičů uvedlo, že příjem domácnosti pokrývá těsně jejich výdaje.

\section{Výsledky}

Konfirmační faktorová analýza dotazníku byla provedena v programu Mplus. Ke zjištění omegy jednotlivých subškál dotazníku ZRA byl použit statistický program R. Ke statistickým analýzám byl použit program IBM SPSS Statistics 25. Data z dotazníku o demografii byla přepsána do SPSS ručně. Odpovědi od adolescentů a jejich matek byly staženy z programu Qualtrics, který již nabízí přepsání dat rovnou do programu SPSS.

\section{Konfirmační faktorová analýza dotazníku zmatení rolí pro adolescenty (ZRA)}

Na datech byla provedena položková analýza a následně také konfirmační faktorová analýza metody pro měření zmatení rolí v rodině. Výsledky položkové analýzy (viz tab. č. 5) poukazují na to, že dvě z původních 16 položek (č. 13 a 14) nejsou pro škálu vhodné, protože mají slabé korigované korelace se skóre škály, a tedy nerozlišují dobře mezi různými úrovněmi zmatení rolí.

TABULKA 5

Popisné statistiky pro Dotazník zmatení rolí

\begin{tabular}{llllllll}
\hline & $M$ & $S D$ & $\begin{array}{l}\min - \\
\max \end{array}$ & & šikmost špičatost & $r_{k s}$ & $\begin{array}{c}\alpha \text { bez } \\
\text { položky }\end{array}$ \\
\hline
\end{tabular}

Instrumentální zmatení rolí

\begin{tabular}{lllllllll}
\hline $\begin{array}{l}\text { 1_Pomáhám rodinným } \\
\text { príslušníkům s úkoly, na které } \\
\text { nestačí. }\end{array}$ & 291 & 2,22 & 1,10 & $1-5$ & 0,66 & $-0,15$ & 0,31 & 0,681 \\
$\begin{array}{l}\text { 2_Uklízím po sobě, ale i po } \\
\begin{array}{l}\text { ostatních nebo vykonávám } \\
\text { domácí práce za ostatní. }\end{array}\end{array}$ & 291 & 2,52 & 1,02 & $1-5$ & 0,17 & $-0,51$ & 0,45 & 0,641 \\
\end{tabular}


TESTFÓRUM, 2020, č. 13, s. 31-60

www.testforum.cz

L. Pivodová, P. Daňsová, L. Lacinová: Dotazník zmatení rolí pro adolescenty: Sdělení o vývoji sebeposuzovací metody

\begin{tabular}{|c|c|c|c|c|c|c|c|c|}
\hline $\begin{array}{l}\text { 3_Bývám zodpovědný za péči o } \\
\text { člena rodiny. }\end{array}$ & 291 & 3,31 & 1,36 & $1-5$ & $-0,01$ & $-1,22$ & 0,46 & 0,635 \\
\hline $\begin{array}{l}\text { 4_Často mám pocit, že se rodina } \\
\text { bez mé pomoci nemǔže obejít. }\end{array}$ & 291 & 3,78 & 1,17 & $1-5$ & $-0,83$ & $-0,12$ & 0,53 & 0,609 \\
\hline $\begin{array}{l}\text { 5_Nastávají situace, kdy } \\
\text { přebírám za rodiče } \\
\text { zodpovědnost. }\end{array}$ & 291 & 4,30 & 1,06 & $1-5$ & $-1,45$ & 1,17 & 0,46 & 0,637 \\
\hline $\begin{array}{l}\text { 6_Někdy vypomáhám rodičǔm s } \\
\text { penězi. }\end{array}$ & 291 & 3,91 & 1,20 & $1-5$ & $-0,79$ & $-0,43$ & 0,33 & 0,679 \\
\hline
\end{tabular}

\section{Emoční zmatení rolí - matka}

\begin{tabular}{|c|c|c|c|c|c|c|c|c|}
\hline $\begin{array}{l}\text { 7_Máma ode mě chce poradit ve } \\
\text { věcech, o kterých si myslím, že } \\
\text { by se měla radit s tátou, nebo s } \\
\text { jinými dospělými. }\end{array}$ & 287 & 3,84 & 1,08 & $1-5$ & $-0,67$ & $-0,22$ & 0,40 & 0,587 \\
\hline $\begin{array}{l}\text { 9_Máma se mně chodí svěřovat } \\
\text { se svými starostmi. }\end{array}$ & 287 & 3,32 & 1,29 & $1-5$ & $-0,27$ & $-1,00$ & 0,45 & 0,558 \\
\hline $\begin{array}{l}\text { 11_Pokud mámu něco trápí, } \\
\text { utěšuji ji. }\end{array}$ & 287 & 2,82 & 1,34 & $1-5$ & 0,24 & $-1,06$ & 0,52 & 0,515 \\
\hline $\begin{array}{l}\text { 13_Máma mně říká, že jsem } \\
\text { stejný/stejná jako táta. }\end{array}$ & 287 & 3,36 & 1,42 & $1-5$ & $-0,31$ & $-1,21$ & 0,18 & 0,695 \\
\hline $\begin{array}{l}\text { 15_Když mámě táta chybí, } \\
\text { nahrazuje jeho přitomnost mojí. }\end{array}$ & 287 & 3,62 & 1,36 & $1-5$ & $-0,57$ & $-0,95$ & 0,46 & 0,553 \\
\hline
\end{tabular}

\section{Emoční zmatení rolí - otec}

\begin{tabular}{|c|c|c|c|c|c|c|c|c|}
\hline $\begin{array}{l}\text { 8_Táta ode mě chce poradit ve } \\
\text { věcech, o kterých si myslím, že } \\
\text { by se měl radit s mámou, nebo s } \\
\text { jinými dospělými. }\end{array}$ & 284 & 4,24 & 0,98 & $1-5$ & $-1,19$ & 1,07 & 0,50 & 0,618 \\
\hline $\begin{array}{l}\text { 10_Táta se mně chodí svěřovat } \\
\text { se svými starostmi. }\end{array}$ & 284 & 4,28 & 1,08 & $1-5$ & $-1,52$ & 1,51 & 0,56 & 0,588 \\
\hline
\end{tabular}


L. Pivodová, P. Daňsová, L. Lacinová: Dotazník zmatení rolí pro adolescenty: Sdělení o vývoji sebeposuzovací metody
12_Pokud tátu něco trápí,
284
3,94
1,25
$1-5$
$-0,91$
$-0,31$
0,55
0,584 utěšuji ho.
14_Táta mně řiká, že jsem
stejný/stejná jako máma.
284
3,79
1,36
1-5 $-0,79$
$-0,65$
0,21
0,748
stejný/stejná jako máma.
16_Když tátovi máma chybí,
$284 \quad 4,15$
1,19
$1-5 \quad-1,35$
0,81
0,47
0,623
nahrazuje její prítomnost mojí.

Poznámka. $\mathrm{r}_{\mathrm{ks}}$ - korigovaná korelace položky se škálou

Instrumentální zmatení rolí má celkem dobré ukazatele reliability (Cronbachova $\alpha=0,689$; omega $=0,685$ ) podobně jako emoční zmatení rolí u matky (Cronbachova $\alpha=0,639$; omega $=0,677$ ), kde jen položka 13 s ostatními položkami škály příliš nekoreluje („Máma o mě ř́lká, že jsem stejný, jako táta.") a její odstranění by zvýšilo vnitřní konzistenci (Cronbachova alpha bez této položky se zvýší na $\alpha=0,695$ ). Emoční zmatení rolí u otce má dobré ukazatele (Cronbachova alpha $\alpha=0,685$; omega $=0,697$ ), položky spolu korelují a také reliabilita je v normě, ale také zde odstranění položky 14 („Táta o mě ř́ká, že jsem stejný jako máma.") zvyšuje vnitřní konzistence škály (Cronbachova alpha bez této položky se zvýší na $\alpha=0,748)$.

Pro ověření faktorové struktury byla použita konfirmační faktorová analýza s odhadem WLSMV (mean- and variance-adjusted weighted least squares) pro ordinální data v programu Mplus. Byl testován tř́faktorový model s 6 položkami instrumentálního zmatení rolí, 5 položkami emočního zmatení rolí k matce a 5 položkami emočního zmatení rolí k otci. Takovýto model vykazoval slabou shodu s daty $\left(\chi^{2}(101)=452.778, \mathrm{p}<0.001 ; \mathrm{CFI}=0.890\right.$; RMSEA = 0.109; WRMR = 1.342), bylo tedy přistoupeno $\mathrm{k}$ respecifikaci modelu. Vzhledem $\mathrm{k}$ problematické položce 13 byl testován nový model bez této položky. Jeho shoda s daty je stále ne prŕliš uspokojivá $\left(\chi^{2}(87)=411.313, \mathrm{p}<0.001 ; \mathrm{CFI}=0.894 ; \mathrm{RMSEA}=0.113\right.$; WRMR = 1.337). Modifikační indexy navrhují korelaci reziduí položek 15 a 16, tedy položek se stejným zněním, pouze se zacílením na matku/otce. Shoda tohoto modelu $\mathrm{s}$ daty je již poměrně uspokojivá $\left(\chi^{2}(86)=328.284, \mathrm{p}<0.001 ; \mathrm{CFI}=0.921\right.$; RMSEA=0.098; WRMR=1.194), nicméně další možností respecifikace, kterou modifikační indexy nabízejí, a která je i věcně odůvodnitelná, je korelace reziduí pro položky 1 a 2 z instrumentálního faktoru (obsahově jde o podobné položky). Shoda tohoto modelu $s$ daty je uspokojivá $\left(\chi^{2}(85)=272.245\right.$, p <.001; CFI=0.939; RMSEA=0.087; WRMR=1.084) a model tedy můžeme považovat za pravděpodobně datům odpovídající. Faktorové náboje ve standardizovaném řešení ukazuje obrázek 3.

\section{OBRÁZEK 3}

Faktorové řešení Dotazníku zmatení rolí ve standardizované podobě bez položky 13 
L. Pivodová, P. Daňsová, L. Lacinová: Dotazník zmatení rolí pro adolescenty: Sdělení o vývoji sebeposuzovací metody

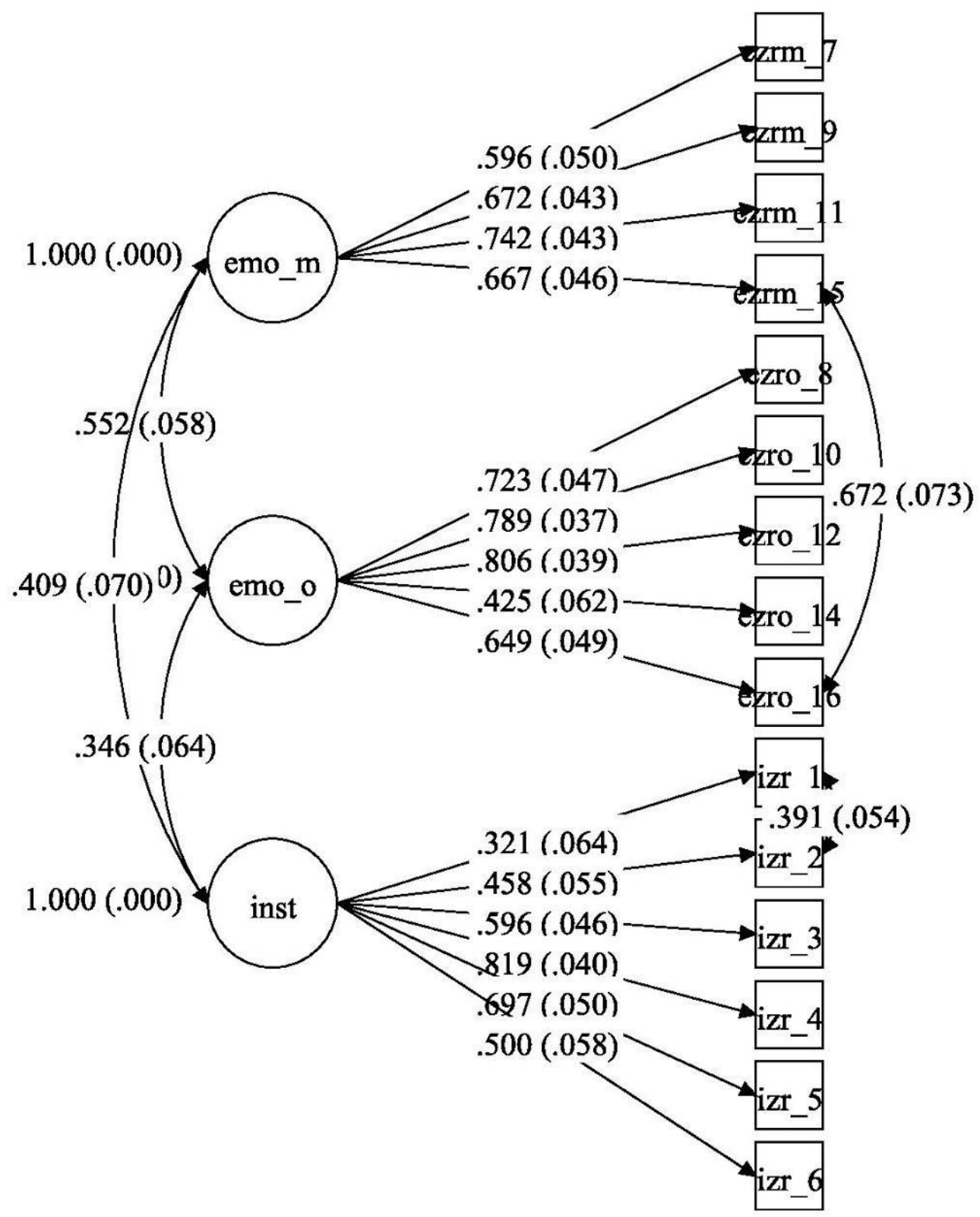

Byla provedena CFA také bez položky 14. Shoda tohoto modelu s daty je uspokojivá $\left(\chi^{2}(72)=234.957, \mathrm{p}<0.001 ; \mathrm{CFI}=0.944 ; \mathrm{RMSEA}=0.088 ; \mathrm{WRMR}=1.058\right)$ a model tedy můžeme považovat za pravděpodobně datům odpovídající. Faktorové náboje ve standardizovaném řešení ukazuje obrázek 4.

\section{OBRÁZEK 4}

Faktorové řešení Dotazníku zmatení rolí ve standardizované podobě bez položky 13 a 14 


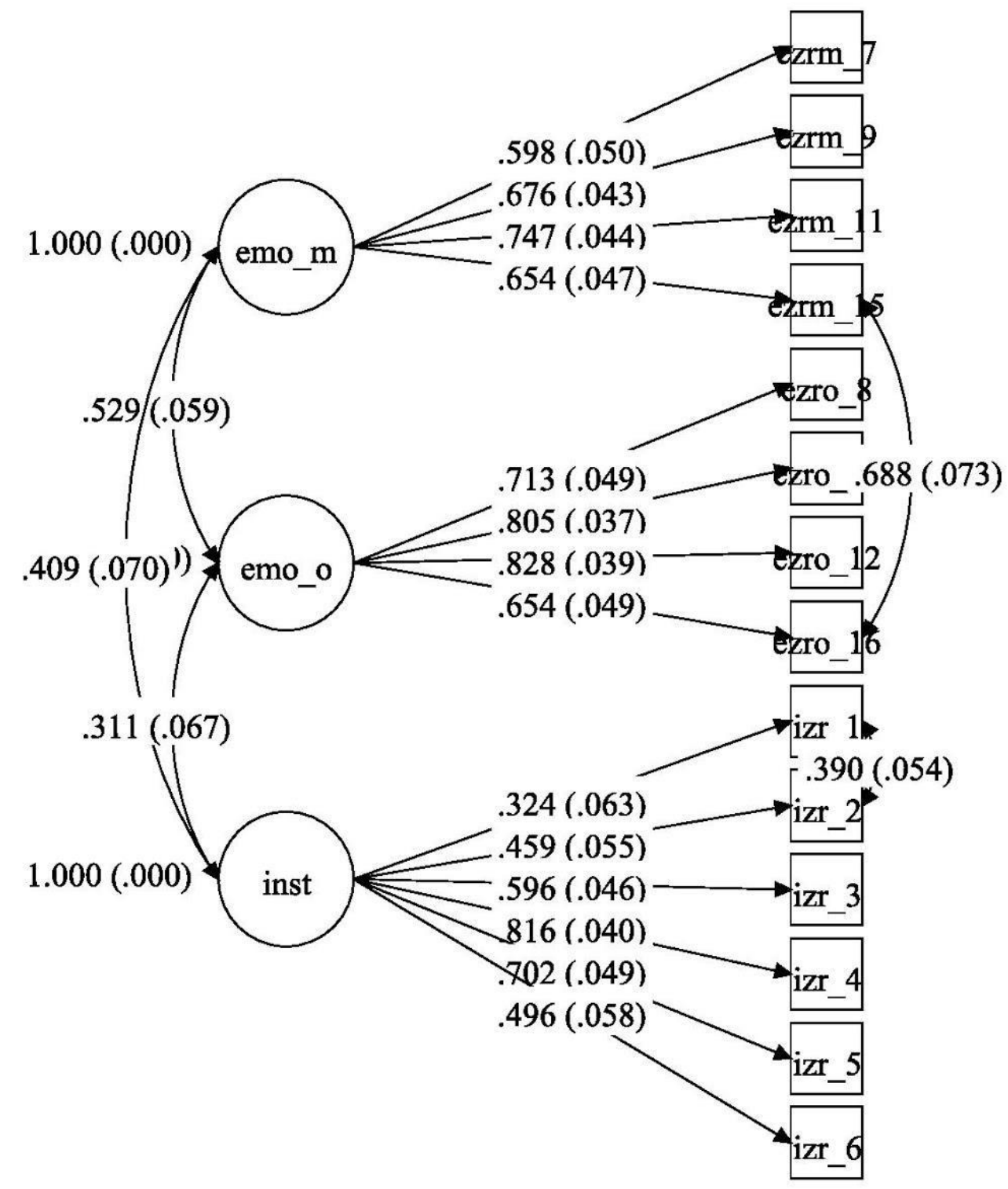

Vzhledem k problematičnosti položky 13 a 14, která se ptá na to, zda o adolescentovi matka/otec říká, že je jako druhý z rodičů, nás zajímalo, zda tyto položky nemají nějaká specifika vzhledem k pohlaví dítěte. Na základě prozkoumání korelační matice je patrné, že položka 13 nekoreluje př́liš s ostatními položkami škály u dívek ani u chlapců, její odstranění by v obou př́ípadech vedlo ke zvýšení vnitřní konzistence škály. Položka 14 u dívek rovněž nekoreluje s ostatními, nicméně u chlapců tato položka zdá se pro škálu vhodná je.

Pokud přistoupíme $\mathrm{k}$ testování konfigurálního modelu pomocí konfirmační faktorové analýzy, abychom zjistili, zda je model se všemi 15 položkami shodný pro dívky i chlapce, je 
L. Pivodová, P. Daňsová, L. Lacinová: Dotazník zmatení rolí pro adolescenty: Sdělení o vývoji sebeposuzovací metody

možné vidět, že u dívek není vhodná pro škálu ani položka 13 ani 14 (slabé sycení, nízký vysvětlený rozptyl položky), u chlapců je položka 13 rovněž problematická, nicméně položka 14 zdá se vhodná je. Shoda modelu u pohlaví, kde jsou povoleny korelace reziduím položek 15 a 16 a 1 a 2 jako u hlavního modelu: $\chi^{2}(198)=460.436$, p<0.001; CFI=0.924; RMSEA=0.095; WRMR=1.337. Shoda tohoto modelu s daty by mohla být dostačující. Nicméně tyto výsledky je potřeba chápat spíše jako explorační, protože dat od chlapců je pouze 91 a korelační matice není tudíž tak stabilní.

V návaznosti na tato zjištění byly tedy položky 13 a 14 z dotazníku vyřazeny. Dotazník zmatení rolí pro adolescenty (ZRA) obsahuje 14 položek, z toho 6 položek $(1,2,3,4,5,6)$ náleží faktoru instrumentální zmatení rolí (IZR), 4 položky $(7,9,11,15)$ emocionální zmatení rolí v dyádě matka/dítě (EZRm) a 4 položky $(8,10,12,16)$ emocionální zmatení rolí v dyádě otec/dítě (EZRo).

\section{Diskuze}

Na vzorku středoškolských negymnaziálních studentů byl ověřován dotazník Zmatení rolí pro adolescenty. Oproti pilotáži ve studii II byly položky dotazníku pozměněny tak, aby stejné položky na emocionální zmatení rolí pro matku a otce nebyly kladeny za sebou, ale pro matku a otce zvlášt', aby se mohl respondent soustředit na odpovědi týkající se jednoho z rodičů a poté druhého. Mezi otázky o matce a otci byly vloženy položky na instrumentální zmatení rolí, které jsou formulovány bez ohledu na jednotlivé rodiče. Z pilotáže prezentované ve studii II vyplynuly jako problematické položky č. 6 a č. 13. Položka č. 6 („Někdy vypomáhám rodičům s penězi (např.: nakoupím ze svých úspor, peníze rodičům půjčím)." zvyšovala nekonzistentnost faktoru instrumentálního zmatení rolí, pro konfirmační faktorovou analýzu byla z pilotáže II odstraněna. Tato skutečnost byla interpretována charakterem souboru - pro pilotáž II byl využit soubor studentů gymnázií z Jihomoravského kraje s vyšším socioekonomickým statusem. Z položkové analýzy současných dat vyplývá, že položka č. 6 pro škálu instrumentální zmatení rolí vhodná je, její korigovaná korelace se škálou je pro škálu uspokojivá. Rodiče adolescentů z učilišt' hodnotili svou ekonomickou situaci průměrně uspokojivě (ani že jsou spíše bohatí, ani že jsou spíše chudí, ale uprostřed tohoto kontinua). Na základě výsledků této studie lze zkonstatovat, že položka, která popisuje typ instrumentální zmatení rolí ve formě půjčení peněz rodičům či nakoupení potřeb do domácnosti za své peníze, je sycena faktorem instrumentálního zmatení rolí.

U položkové analýzy položky č. 13 („Máma o mně ř́ká, že jsem stejný/stejná jako táta.“) se podobně jako u pilotáže II zopakovala slabá korigovaná korelace položky se škálou. Položka č. 14, která je formulovaná pro otce („Táta o mně ř́ká, že jsem stejný/stejná jako máma. “), má u vzorku současných negymnaziálních respondentů také slabou korigovanou korelaci položky se škálou. Zajímalo nás, zda tyto položky mohou být podmíněny genderově. Tzn., zda 
L. Pivodová, P. Daňsová, L. Lacinová: Dotazník zmatení rolí pro adolescenty: Sdělení o vývoji sebeposuzovací metody

se může lišit např́klad pokud dcera může vypovídat pouze o otci, že jí připisuje charakteristiky matky (kterou například „nemůže vystát“) a podobně i u chlapců. Nicméně na základě analýzy nebylo možno tento rozdíl na základě genderu podpořit. Byla provedena konfirmační faktorová analýza bez položky 13 a také bez položky 13 a 14. Struktura faktorů emocionální zmatení rolí v dyádě matka-dítě a otec-dítě se ukázala jako vhodná bez použití těchto dvou položek. Položky 13 a 14 měly odkazovat na emocionální vztah rodiče k dítěti, kdy rodič připisuje vlastnosti dítěti, které má či nemá rád u svého partnera. Při formulaci těchto dvou položek jsme vycházeli mimo jiné i z kvalitativního výzkumu (Pivodová \& Lacinová, 2016). Výroky adolescentů popisovaly tento typ chování rodičů ke svým dětem. Nicméně adolescenti tento vztah pouze popisovali a není zřejmé, jaký význam tomuto chování adolescenti připisují. Není jasné, zda právě partnerské chování rodičů k nim formou připisování vlastností druhého rodiče (a to jak pozitivních vlastností, ale převážně vlastností negativních), dokázali jako partnerské ve svém vývojovém období vnímat. Domníváme se, že tento typ položek není vhodný do dotazníku pro adolescenty, nicméně by byl vhodný pro dospělé, kteří toto chování retrospektivně budou vnímat jako partnerské (v hostilním významu).

Snahou naší studie bylo vyhnout se tzv. výběrovému souboru populace s vyšším socioekonomickým statusem, se kterým se můžeme setkat na gymnáziích a ve větších městech (jak bylo i v našem případě v pilotáži ve studii II). Záměrně jsme výzkum zacílili na negymnaziální střední školy, tedy SŠ s maturitou a učiliště mimo velká města. Nicméně tento výběr, jak se ukázalo, se stal také velkým limitem dané studie. Při domlouvání výzkumu v jednotlivých školách jsme se setkávali s velkou nedůvěrou jak ze strany škol, tak ze strany rodičů. Distribuováno bylo 1922 žádostí o účast ve výzkumu s informovaným souhlasem, nicméně do studie se zapojilo 293 adolescentů, což je pouze 15,2 \% z původně oslovených. Společných zodpovězených dotazníků matek s jejich dětmi bylo 123 což je pouze 6,5 \% všech oslovených. Po rozhovorech s kontaktními osobami (většinou školními psychology či výchovnými poradci) se domníváme, že s administrací dotazníků souhlasili většinou rodiče z rodin, které kontaktní osoby považovaly spíše za bezproblémové. Z demografických údajů naší studie vyplývá, že 64,6 \% respondentů bylo z úplných rodin. Odhad kontaktních osob byl mnohem nižší (děti z úplných rodin na SŠ zmiňovaly kolem 20 \%). Vzorek je tedy výrazně zkreslen ochotou popsat rodinné prostředí, ve kterém aktuálně respondent žije a také velkou nedůvěrou svěřovat se do dotazníku.

\section{Závěr}

Hlavním záměrem při tvorbě sebehodnotícího dotazníku, jehož podobu představila tato studie, bylo umožnit zachytit subjektivní percepci zmatení rolí v rodině pohledem dospívajících. Díky této metodě se otevírají další možnosti např́íklad zkoumat jaký vliv má fenomén zmatení rolí na vývoj a adaptaci dětí/adolescentů v jednotlivých dyádách 
L. Pivodová, P. Daňsová, L. Lacinová: Dotazník zmatení rolí pro adolescenty: Sdělení o vývoji sebeposuzovací metody

(matka/dcera, matka/syn, otec/dcera, otce/syn). Dotazník zmatení rolí může usnadnit rychlejší orientaci týkající se narušení hranic rodinného systému. Nicméně je potřeba konstatovat, že tento dotazník primárně vzniká jako výzkumná metoda, která není určena pro diagnostické užití v klinické a poradenské praxi.

Domníváme se, že jsme vyvinuli nástroj, který by mohl pomoci objasnit fungování rodičovsko-dětských dyád a díky němuž bude možné získávat poznatky o souvislostech mezi typy zmatení rolí a proměnnými používanými k zachycení míry adaptace a psychického zdraví jako je např́íklad emocionalita, externalizované a internalizované chování, nebo sebehodnocení. Díky této metodě můžeme lépe porozumět tomu, jak narušení hranic rodinného systému ovlivňuje vývoj a adaptaci chlapců a dívek specificky. Zmatení rolí ve svých různorodých projevech je poměrně častým prediktorem obtíží adolescentů - a to jak externalizovaného chování jako je agresivita, projevy násilí vůči okolí, poruchy chování, tak internalizovaného chování, jako časté depresivní symptomy, nízká sebedůvěra. Někteří autoři mluví o zmatení rolí dokonce jako o jisté formě zneužití dítěte. Zároveň zmatení rolí do určité míry nemusí přinášet pouze negativní efekty, ale za určitých okolností (jako je např. krátkodobost; kompetence, které jsou ve vývojovém období dítěte zvládnutelné) lze pozorovat přítomnost benefitů pro rozvoj dospívajících (jako např.: zvýšení sebedůvěry, některé kompetence adolescent zvládl dříve než vrstevníci, kvalitnější intrepersonální vztahy). Záleží i na kontextu situace a vnímání přelévání kompetencí z rodičů na děti v kontextu kultury, ve které se distribuce zodpovědnosti, úkolů a kompetencí odehrává.

Pokud budeme tedy detailněji zkoumat podobu narušení hranic v rodinách a jejich dopadů, můžeme přispět těmito poznatky v oblasti poradenství a rodinné terapie. $\mathrm{S}$ pochopením souvislostí a specifik zmatení rolí mohou poradci a psychoterapeuti účinněji adolescentům či celým rodinám pomáhat obnovovat harmonii v jejich vzájemných vztazích nebo zmatení rolí adolescentům pomoci reflektovat a nacházet strategie, jak se s danou situací vyrovnávat.

\section{Literatura}

Aber, J., Slade, A., Berger, B., Bresgi, I., \& Kaplan, M. (1985). The parent development interview. Unpublished protocol, The City University of New York, NY, USA

Afifi, T. D., \& Schrodt, P. (2003). "Feeling caught" as a mediator of adolescents' and young adults' avoidance and satisfaction with their parents in divorced and nondivorced households. Communication Monographs, 70, 142 - 173.

Amato, P. R., \& Afifi, T. D. (2006). Feeling Caught Between Parents: Adult Children's Relations With Parents and Subjective Well-Being. Journal of Marriage and Family, 68,222-235

Button, S., Pianta, R. C., \& Marvin, R. S. (2001). Mother's representations of relationships with their children: Relations with parenting behaviormother characteristrics, and child disability status. Social Development., 10 (4), 455-472, doi: 10.1111/1467-9507.00175 
L. Pivodová, P. Daňsová, L. Lacinová: Dotazník zmatení rolí pro adolescenty: Sdělení o vývoji sebeposuzovací metody

Byng-Hall, J. (2002). Relieving Parentified Children's Burdens in Families with Insecure Attachment Patterns. Family Process, 41(3), 375-388

Bronfebrenner, U. (1979). The ecology of human development. Cambridge, MA: Harvard University Press

Cassidy, J., Marvin, R.S., \& the McArthur Working Group on Attachment. (1992). Attachment organization in 2 to 4 year olds: Coding manual. Unpublished coding manual. University of Virginia, Charlottes ville.

Fullinwider-Bush, N., \& Jacobvitz, D. B. (1993). The transition to young adulthood: Generational boundary dissolution and female identity development. Family Process, 32(1), 87-103. doi:10.1111/j.1545-5300.1993.00087.x

George, C., \& Solomon, J. (1989). Internal working models of caregiving and security of attachment at age six. Infant Mental Health Journal, 10 (3), 222- 237.

George, C., \& Solomon, J. (2008): Caregiving helplessness: Development of a Questionnaire to Sreening Measure for Disorganized Maternal Caregiving. (neplublikovaná práce). Mills Collage, Okland CA

George, C., \& Solomon, J. (2011). Caregiving helplessness: The development of a screening measure for maternal caregiving disorganization. In J. Solomon \& C. George (Eds.), Disorganized attachment and caregiving (pp. 133-166). New York: Guilford Press.

Grych, J. H. \& Fincham, F. D. (1990). Marital conflict and children's adjustment: A cognitive-contextual framework. Psychological Bulletin, 108, 267-272

Hardway, C., Fuligni A., J. (2006). Dimensions of family connectedness among adolescents with Chinese, Mexican, and European backgrounds. Developmental Psychology, 42, 1246-1258.

Hooper, L. M., Wallalce, S. A. (2010).: Evaluating the Parentification Questionnaire: Psychometric Properties and Psychopathology Correlates. Contemporary Familly Theories (32), 52-68, DOI 10.1007/s10591-009-9

Hooper, L. M., Doelher, K., Wallace, S. A., \& Hannah N., J. (2011).: The Parentification Inventory: Development, Validation, and Cross-Validation. The American Journal of Family Therapy (39), 226-241 103-9

Jurkovic, G. J., \& Thirkield, A. (1998).Parentification Questionnaire (Available from G. J. Jurkovic, Department of Psychology, Georgia State University, University Plaza, Atlanta, GA 30303).

Jurkovic, G. J. (1997). The plight of the parentified child. New York: Brunner Mazel, Inc.

Jurkovic, G. J. (1998). Destructive parentification in families: Causes and consequences. In L. L'Abate (Ed.), Family psychopathology (pp. 237-255). New York: The Guilford Press.

Jurkovic, G. J., Thirkield, A., \& Morrell, R. (2001). Parentification of adult children of divorce: A multidimensional analysis. Journal of Youth and Adolescence, 30, 245 - 257

Katz, J., Petracca, M. \& Rabinowitz, J. A (2009). Retrospective Study of Daughters' Emotional Role Reversal with Parents, Attachment Anxiety, Excessive Reassurance-Seeking, and Depressive Symptoms. The American Journal of Family Therapy, 37, 185-195, DOI: 10.1080/01926180802405596 
L. Pivodová, P. Daňsová, L. Lacinová: Dotazník zmatení rolí pro adolescenty: Sdělení o vývoji sebeposuzovací metody

Koerner, S. S., Wallace, S., \& Jacobs Lehman, S. (2004). Sensitive mother-toadolescent disclosures after divorce: Is the experience of sons different from that of daughters? Journal of Family Psychology, 18, 46 - 57.

Lewandowska-Walter, A., Borchet, J., Rostowska, T., Polomski, P., \& Peplinska, A. (2017). Parentification and coping in polish adolescents. Polish Journal of Social Science, 11(1), 157-176.

Lyons-Ruth, K., Bureau, J.-F., Riley, C., \& Atlas-Corbett, A.F. (2009). Socially indiscriminate attachment behavior in the Strange Situation: Convergent and discriminant validity in relation to caregiving risk, later behavior problems, and attachment insecurity. Development and Psychopathology, 21(2), 355- 372.

Macfie, J; Brumariu, L. E.; \& Lyons-Ruth, K. (2015). Parent-Child Role-Confusion: A critical Review of an Emerging Concept, Developmental Review. DOI: 10.1016/j.dr.2015.01.002

Macafie, J., Houts, R., McElwain, N. L., \& Cox, M. J. (2005). The Effect of Father-Toddler and MotherToddler Role Reversal on the Development of Behavior Problems in Kindergarten. Social Development. 14 (3), 514-531, DOI: 10.1111/j.1467-9507.2005.00314.x

Mayseless, O., Bartholomew, K., Henderson, A., \& Trinke, S. (2004). "I was more her mom than she was mine." Role reversal in a community sample. Family Relations, 53, 78-86

Mayseless, 0., \& Scharf, M. (2009). Too Close for Comfort: Inadequate Boundaries With Parents and Individuation in Late Adolescent Girls. American Journal of Orthopsychiatry, 79. (2), 191-202, DOI: $10.1037 / \mathrm{a} 0015623$

Mika, P., Bergner, R. M., \& Baum, M. C. (1987). The development of a scale for the assessment of parentification. Family Therapy, 14(3), 229-235.

Nuttall, A. K., Valentino, K., \& Borkowski, J. G. (2012): Maternal History of Parentification, Maternal Warm Responsiveness, and Children's Externalizing Behavior. Journal of Family Psychology. 26 (5), 767-775. DOI: 10.1037/a0029470

Perrin, M. B., Ehrenberg, M. F. \& Hunter, M. (2013). Boundary Diffusion, Individuation, and Adjustment: Comparison of Young Adults Raised in Divorced Versus Intact Families. Family Relations 62, 768 - 782, DOI:10.1111/fare.12040

Pivodová, L., Lacinová, L. (2016).: Fenomén spousifikace: Studie o partnerském vztahu mezi rodičem a dítětem. E-psychologie (10), 1

Shier, K., Herke, M., Nickel, R., Elge, U. T. \& Hardt, J. (2015): Long-Term Sequelae of Emotional Parentification: A Cross-Validation Study Using Sequences of Regressions, Journal of Children and Family Studies, 24, 1307-1321, DOI 10.1007/s10826-014-9938-z

Sroufe, L. A., Jacobvitz, D., Mangelsdorf, S., DeAngelo, E., \& Ward, J. J. (1985). Generational boundary dissolution between mothers and their preschool children: A relationship systems approach. Child Development, 56, 317- 332.

Solomon, J., \& George, C. (1996). Defining the caregiving system: Toward a theory of caregiving. Infant Mental Health Journal, 17 (3), 183- 197. 
L. Pivodová, P. Daňsová, L. Lacinová: Dotazník zmatení rolí pro adolescenty: Sdělení o vývoji sebeposuzovací metody

Solomon, J., George, C., \& De Jong, A. (1995). Children classified as a controlling at age six.: Evidence of disorganized representation strategies and aggression at home and at school. Development and Psychology, 7 (447-463).

Trentacosta, Ch. J., Criss, M. M., Shaw, D. S., Lacourse, E., Hyde, L. W., \& Dishion, T. J. 2011). Antecedents and Outcomes of Joint Trajectories of MotherSon Conflict and Warmth During Middle Childhood and Adolescence, Child Development, 82 (5), 1676-1690

Van der Mijl, R. C. W., \& Vingerhoets, A. J. J. M. (2017). The Positive Effects of Parentification: An Exploratory Study among Students. Psihologijske teme, 26(2), 417-430.

Vulliez-Coady, L., \& Lyons-Ruth, K. (2009). Parental Assassment of Role Confusion Scale: Coding Manulal Measure Instrument, Cambridge, MA, USA: Harvard University

Vulliez - Coady, L., Obsuth, I., Torreiro Casal, M., Ellertsdottir, L. \& Lyons - Ruth, K. (2013): Maternal role confusion: Relations to maternal attechment and mother-child interactin from infancy to adolescence. Infant Mental Health Journal, 34(2), 117-131, DOI: 10.1002/imhj.

Vulliez - Coady, L., Solheim, E., Nahum, J. P., \& Lyons - Ruth, K. (2016). Role-Confusion in Parent-Child Relationships: Assessing Mother's Representations and its Implications for Counselling and Psychotherapy Practice. The European Journal of Counselling Psychology. 4(2), 1-23, DOI: 10.5964/ejcop.v4i2.62 

metody

\title{
Dotazník zmatení rolí pro adolescenty: Sdělení o vývoji sebeposuzovací metody
}

\begin{abstract}
The aim of the study was to develop a questionnaire to capture the degree of role confusion as it is currently experienced by adolescents. The process of creating a questionnaire is described through two follow-up studies. In Study I, 9 self-assessment items were piloted on a sample of adolescents ( $n=56 ; 13-17$ years; $M=15,02 ; S D=1,8 ; 65,5 \%$ girls). The internal consistency and factor relevance of the items into two factors was verified - instrumental role confusion and emotional role confusion. In Study II, 16 questionnaire items (existing from Study I, amended and supplemented) were piloted on a sample of adolescents ( $n=154 ; 12-19$ years; $M=15,23 ; S D=2,02 ; 61,7 \%$ girls). The distinction of role confusion towards father and mother was differentiated, the items being divided into three factors: instrumental role confusion, emotional role confusion in the mother / child dyad, and emotional role confusion in father / child dyad. Since the content-related items for the mother and father were administered one after another and shared the variance, which was not possible to explain their belonging to the scales, the questionnaire with different order of items were subjected to quntitative study III. The research sample consisted of high school students ( $n=293 ; 15-21$ years, $M=16,23 ; 67,6 \%$ girls). The factor structure of the ZRA questionnaire was verified by confirmatory factor analysis.
\end{abstract}

Keywords: Role confusion; questionnaire; adolescence; self-reported method; parent-child dyads 
L. Pivodová, P. Daňsová, L. Lacinová: Dotazník zmatení rolí pro adolescenty: Sdělení o vývoji sebeposuzovací metody

Př́lohy

Přiloha 1: Znění dotazníku zmatení rolí před kognitivním interview

Pozorně si prosím přečti následující výroky a u každého zvaž, do jaké míry tě vystihuje a jak to u vás doma chodí.

Zakroužkuj pak tu variantu, která ti nejlépe sedí.

\begin{tabular}{|c|c|c|c|c|c|}
\hline & $\begin{array}{l}\text { Vůbec mne } \\
\text { to } \\
\text { nevystihuje }\end{array}$ & $\begin{array}{l}\text { Spíše mne to } \\
\text { nevystihuje }\end{array}$ & $\begin{array}{l}\text { Někdy mne } \\
\text { to vystihuje, } \\
\text { někdy } \\
\text { nevystihuje }\end{array}$ & $\begin{array}{l}\text { Spíše mne to } \\
\text { vystihuje }\end{array}$ & $\begin{array}{l}\text { Úplně mne to } \\
\text { vystihuje }\end{array}$ \\
\hline $\begin{array}{l}\text { Pro rodinu dělám věci, } \\
\text { kterých si často nikdo ani } \\
\text { nevšimne. }\end{array}$ & 1 & 2 & 3 & 4 & 5 \\
\hline $\begin{array}{l}\text { Máma nebo táta se mi } \\
\text { často svěřují se svými } \\
\text { problémy. }\end{array}$ & 1 & 2 & 3 & 4 & 5 \\
\hline $\begin{array}{l}\text { Máma nebo táta za mnou } \\
\text { chodí pro radu ve věcech, o } \\
\text { kterých by měli rozhodovat } \\
\text { spíš oni sami. }\end{array}$ & 1 & 2 & 3 & 4 & 5 \\
\hline $\begin{array}{l}\text { Pokud mámu nebo tátu } \\
\text { něco trápí, utěšuji ji/ho. }\end{array}$ & 1 & 2 & 3 & 4 & 5 \\
\hline $\begin{array}{l}\text { Často doma nakupuji pro } \\
\text { celou rodinu. }\end{array}$ & 1 & 2 & 3 & 4 & 5 \\
\hline $\begin{array}{l}\text { Pomáhám rodičům } \\
\text { zvládnout finanční } \\
\text { problémy (např. nakupuji, } \\
\text { platím některé účty). }\end{array}$ & 1 & 2 & 3 & 4 & 5 \\
\hline $\begin{array}{l}\text { Pomáhám rodinným } \\
\text { příslušníkům s úkoly, na } \\
\text { které nestačí (např. } \\
\text { sourozencům s domácími } \\
\text { úkoly, babičce s nákupem). }\end{array}$ & 1 & 2 & 3 & 4 & 5 \\
\hline $\begin{array}{l}\text { Často bývám zodpovědný } \\
\text { za péči o člena rodiny } \\
\text { (např. umývání, krmení, } \\
\text { oblékání sourozence či } \\
\text { pomoc nemocným } \\
\text { prarodičům). }\end{array}$ & 1 & 2 & 3 & 4 & 5 \\
\hline $\begin{array}{l}\text { Často doma uklízím nejen } \\
\text { po sobě, ale i po ostatních }\end{array}$ & 1 & 2 & 3 & 4 & 5 \\
\hline
\end{tabular}


L. Pivodová, P. Daňsová, L. Lacinová: Dotazník zmatení rolí pro adolescenty: Sdělení o vývoji sebeposuzovací metody

(např. po mladším

sourozenci, po rodičích).

Přiloha 2: Dotazník Zmatení rolí pro adolescenty pro Pilotáž I

Pozorně si prosím přečti následující výroky a u každého zvaž, do jaké míry tě vystihuje a jak to u vás doma chodí.

Zakroužkuj pak tu variantu, která ti nejlépe sedí.

\begin{tabular}{|c|c|c|c|c|c|}
\hline & $\begin{array}{l}\text { Úplně to } \\
\text { na mě } \\
\text { sedí }\end{array}$ & $\begin{array}{l}\text { Spíš to } \\
\text { na mě } \\
\text { sedí }\end{array}$ & $\begin{array}{l}\text { Někdy to } \\
\text { na mě } \\
\text { sedí, } \\
\text { někdy } \\
\text { ne }\end{array}$ & $\begin{array}{l}\text { Spíš to } \\
\text { na mě } \\
\text { nesedí }\end{array}$ & $\begin{array}{l}\text { Vůbec to na } \\
\text { mě nesedí }\end{array}$ \\
\hline $\begin{array}{l}\text { A_Stává se, že když s něčím } \\
\text { doma pomúžu, nikdo si toho ani } \\
\text { nevšimne. }\end{array}$ & 1 & 2 & 3 & 4 & 5 \\
\hline $\begin{array}{l}\text { B_Máma nebo táta se za mnou } \\
\text { chodí svěřovat s jejich starostmi. }\end{array}$ & 1 & 2 & 3 & 4 & 5 \\
\hline $\begin{array}{l}\text { C_Máma nebo táta ode mě chtějí } \\
\text { poradit ve věcech, o kterých si } \\
\text { myslím, že by se měli radit mezi } \\
\text { sebou nebo s jinými dospělými. }\end{array}$ & 1 & 2 & 3 & 4 & 5 \\
\hline $\begin{array}{l}\text { D_Pokud mámu nebo tátu něco } \\
\text { trápí, utěšuji ji/ho. }\end{array}$ & 1 & 2 & 3 & 4 & 5 \\
\hline $\begin{array}{l}\text { E_Chodím sám/sama nakupovat } \\
\text { pro celou rodinu. }\end{array}$ & 1 & 2 & 3 & 4 & 5 \\
\hline $\begin{array}{l}\text { F_Někdy vypomáhám rodičům s } \\
\text { penězi (např. nakoupím ze svých } \\
\text { úspor, peníze rodičům půjčím). }\end{array}$ & 1 & 2 & 3 & 4 & 5 \\
\hline $\begin{array}{l}\text { G_Pomáhám rodinným } \\
\text { příslušníkům s úkoly, na které } \\
\text { nestačí (např. sourozencům s } \\
\text { domácími úkoly, babičce s } \\
\text { nákupem, mámě se žehlením). }\end{array}$ & 1 & 2 & 3 & 4 & 5 \\
\hline $\begin{array}{l}\text { H_Bývám zodpovědný za péči o } \\
\text { člena rodiny (např. umývání, } \\
\text { krmení, oblékání sourozence, } \\
\text { pomoc nemocným rodičům či } \\
\text { prarodičům). }\end{array}$ & 1 & 2 & 3 & 4 & 5 \\
\hline $\begin{array}{l}\text { I_Uklízím doma po sobě, ale i po } \\
\text { ostatních (např. po mladším } \\
\text { sourozenci, po rodičích), nebo } \\
\text { vykonávám domácí práce za } \\
\text { ostatní (např. vařím, peru). }\end{array}$ & 1 & 2 & 3 & 4 & 5 \\
\hline
\end{tabular}


L. Pivodová, P. Daňsová, L. Lacinová: Dotazník zmatení rolí pro adolescenty: Sdělení o vývoji sebeposuzovací metody

Přiloha 3: Znění dotazníku Zmatení rolí pro Pilotáž II

Pozorně si prosím přečti následující výroky a u každého zvaž, do jaké míry tě vystihuje a jak to u vás doma chodí.

Zakroužkuj pak tu variantu, která ti nejlépe sedí.

\begin{tabular}{|c|c|c|c|c|c|}
\hline & $\begin{array}{l}\text { Úplně } \\
\text { to na } \\
\text { mě } \\
\text { sedí }\end{array}$ & $\begin{array}{l}\text { Spíš to } \\
\text { na mě } \\
\text { sedí }\end{array}$ & $\begin{array}{l}\text { Někdy } \\
\text { to na } \\
\text { mě } \\
\text { sedí, } \\
\text { někdy } \\
\text { ne }\end{array}$ & $\begin{array}{l}\text { Spíš to } \\
\text { na mě } \\
\text { nesedí }\end{array}$ & $\begin{array}{l}\text { Vůbec } \\
\text { to na } \\
\text { mě } \\
\text { nesedí }\end{array}$ \\
\hline $\begin{array}{l}\text { 1_Pomáhám rodinným př́slušníkům s úkoly, na které } \\
\text { nestačí (např.: sourozencům s domácími úkoly, } \\
\text { babičce s nákupem, mámě se žehlením). }\end{array}$ & 1 & 2 & 3 & 4 & 5 \\
\hline $\begin{array}{l}\text { 2_Uklízím po sobě, ale i po ostatních (např. po } \\
\text { mladším sourozenci, po rodičích), nebo vykonávám } \\
\text { domácí práce za ostatní (např. vařím, peru). }\end{array}$ & 1 & 2 & 3 & 4 & 5 \\
\hline $\begin{array}{l}\text { 3_Bývám zodpovědný za péči o člena rodiny (např. } \\
\text { umývání, krmení, oblékání sourozence, pomoc } \\
\text { nemocným rodičům či prarodičům). }\end{array}$ & 1 & 2 & 3 & 4 & 5 \\
\hline $\begin{array}{l}\text { 4_Často mám pocit, že se rodina bez mé pomoci } \\
\text { nemǔže obejít. }\end{array}$ & 1 & 2 & 3 & 4 & 5 \\
\hline $\begin{array}{l}\text { 5_Nastávají situace, kdy přebírám za rodiče } \\
\text { zodpovědnost (např. vyřizuji za rodiče platby za } \\
\text { domácnost, pomáhám jim v jejich zaměstnání). }\end{array}$ & 1 & 2 & 3 & 4 & 5 \\
\hline $\begin{array}{l}\text { 6_Někdy vypomáhám rodičům s penězi (např.: } \\
\text { nakoupím ze svých úspor, peníze rodičům půjčím). }\end{array}$ & 1 & 2 & 3 & 4 & 5 \\
\hline
\end{tabular}

Následující dvojice otázek jsou podobné, liší se pouze tím, zda se týkají tvé mámy či táty.

Nyní se prosím zamysli, do jaké míry tyto výroky vystihují každého rodiče zvlášt́.

Zakroužkuj tu variant, která ti nejlépe sedí. 
L. Pivodová, P. Daňsová, L. Lacinová: Dotazník zmatení rolí pro adolescenty: Sdělení o vývoji sebeposuzovací metody

\begin{tabular}{|l|l|l|l|l|l|}
\hline $\begin{array}{l}\text { 7_Máma ode mě chce poradit ve věcech, o kterých si } \\
\text { myslím, že by se měla radit s tátou, nebo s jinými } \\
\text { dospělými. }\end{array}$ & 1 & 2 & 3 & 4 & 5 \\
\hline $\begin{array}{l}\text { 8_Táta ode mě chce poradit ve věcech, o kterých si } \\
\text { myslím, že by se měl radit s mámou, nebo s jinými } \\
\text { dospělými. }\end{array}$ & 1 & 2 & 3 & 4 & 5 \\
\hline
\end{tabular}

\begin{tabular}{|l|l|l|l|l|l|l|}
\hline 9_Máma se mně chodí svěřovat se svými starostmi. & 1 & 2 & 3 & 4 & 5 \\
\hline 10_Táta se mně chodí svěřovat se svými starostmi. & 1 & 2 & 3 & 4 & 5 \\
\hline
\end{tabular}

\begin{tabular}{|l|l|l|l|l|l|}
\hline 11_Pokud mámu něco trápí, utěšuju ji. & 1 & 2 & 3 & 4 & 5 \\
\hline 12_Pokud tátu něco trápí, utěšuju ho. & 1 & 2 & 3 & 4 & 5 \\
\hline
\end{tabular}

\begin{tabular}{|l|l|l|l|l|l|l|}
\hline 13_Máma mně říká, že jsem stejný/stejná jako táta. & 1 & 2 & 3 & 4 & 5 \\
\hline 14_Táta mně říká, že jsem stejný/stejná jako máma. & 1 & 2 & 3 & 4 & 5 \\
\hline
\end{tabular}

\begin{tabular}{|l|l|l|l|l|l|}
\hline $\begin{array}{l}\text { 15_Když mámě táta chybí, nahrazuje jeho př́tomnost } \\
\text { mojí (např. díváme se spolu na filmy, které se líbí } \\
\text { mámě, obejme mě, když je jí smutno). }\end{array}$ & 1 & 2 & 3 & 4 & 5 \\
\hline $\begin{array}{l}\text { 16_Když tátovi máma chybí, nahrazuje její př́tomnost } \\
\text { mojí (např. díváme se spolu na filmy, které se líbí } \\
\text { tátovi, obejme mě, když je mu smutno). }\end{array}$ & 1 & 2 & 3 & 4 & 5 \\
\hline
\end{tabular}

PŘíLOHA 4: Znění dotazníku zmatení rolí pro výzkum

Nyní si, prosím, přečti následující výroky a u každého zvaž, do jaké míry tě vystihuje a jak to u vás doma chodí.

Nejprve se zamysli, do jaké míry tyto výroky vystihují tvou mámu.

\section{Zakroužkuj pak tu variantu, která ti nejlépe sedí.}


L. Pivodová, P. Daňsová, L. Lacinová: Dotazník zmatení rolí pro adolescenty: Sdělení o vývoji sebeposuzovací metody

\begin{tabular}{|c|c|c|c|c|c|}
\hline & $\begin{array}{l}\text { Úplně } \\
\text { to na } \\
\text { mě } \\
\text { sedí }\end{array}$ & $\begin{array}{l}\text { Spíš to } \\
\text { na mě } \\
\text { sedí }\end{array}$ & $\begin{array}{l}\text { Někdy to } \\
\text { na mě } \\
\text { sedí, } \\
\text { někdy ne }\end{array}$ & $\begin{array}{l}\text { Spíš to } \\
\text { na mě } \\
\text { nesedí }\end{array}$ & $\begin{array}{l}\text { Vůbec to } \\
\text { na mě } \\
\text { nesedí }\end{array}$ \\
\hline $\begin{array}{l}\text { Máma ode mě chce poradit ve } \\
\text { věcech, o kterých si myslím, že by } \\
\text { se měla radit s tátou, nebo s jinými } \\
\text { dospělými. }\end{array}$ & 1 & 2 & 3 & 4 & 5 \\
\hline $\begin{array}{l}\text { Máma se mně chodí svěřovat se } \\
\text { svými starostmi. }\end{array}$ & 1 & 2 & 3 & 4 & 5 \\
\hline Pokud mámu něco trápí, utěšuju ji. & 1 & 2 & 3 & 4 & 5 \\
\hline $\begin{array}{l}\text { Máma mně říká, že jsem } \\
\text { stejný/stejná jako táta. }\end{array}$ & 1 & 2 & 3 & 4 & 5 \\
\hline $\begin{array}{l}\text { Když mámě táta chybí, nahrazuje } \\
\text { jeho př́tomnost mou (např. díváme } \\
\text { se spolu na filmy, které se líbí } \\
\text { mámě, obejme mě, když je jí } \\
\text { smutno,...). }\end{array}$ & 1 & 2 & 3 & 4 & 5 \\
\hline
\end{tabular}

Nyní následují otázky, které se týkají obou tvých rodičů.

Zakroužkuj tu variantu, která ti nejlépe sedí.

\begin{tabular}{|l|c|c|c|c|c|}
\hline & $\begin{array}{c}\text { Úplně to } \\
\text { na mě } \\
\text { sedí }\end{array}$ & $\begin{array}{c}\text { Spíš to } \\
\text { na mě } \\
\text { sedí }\end{array}$ & $\begin{array}{c}\text { Někdy to } \\
\text { na mě } \\
\text { sedí, } \\
\text { někdy ne }\end{array}$ & $\begin{array}{c}\text { Spíš to } \\
\text { na mě } \\
\text { nesedí }\end{array}$ & $\begin{array}{c}\text { Vůbec to } \\
\text { na mě } \\
\text { nesedí }\end{array}$ \\
\hline $\begin{array}{l}\text { Pomáhám rodinným příslušníkům } \\
\text { s úkoly, na které nestačí (např.: } \\
\text { sourozencům s domácími úkoly, } \\
\text { babičce s nákupem, mámě se } \\
\text { žehlením). }\end{array}$ & 1 & 2 & 3 & 4 & 5 \\
\hline $\begin{array}{l}\text { Uklízím po sobě, ale i po ostatních } \\
\text { (např. po mladším sourozenci, po } \\
\text { rodičích), nebo vykonávám }\end{array}$ & 1 & 2 & 3 & 4 & \\
\hline
\end{tabular}


L. Pivodová, P. Daňsová, L. Lacinová: Dotazník zmatení rolí pro adolescenty: Sdělení o vývoji sebeposuzovací metody

\begin{tabular}{|c|c|c|c|c|c|}
\hline $\begin{array}{l}\text { domácí práce za ostatní (např. } \\
\text { vařím, peru). }\end{array}$ & & & & & \\
\hline $\begin{array}{l}\text { Bývám zodpovědný za péči o } \\
\text { člena rodiny (např. umývání, } \\
\text { krmení, oblékání sourozence, } \\
\text { pomoc nemocným rodičům či } \\
\text { prarodičům). }\end{array}$ & 1 & 2 & 3 & 4 & 5 \\
\hline $\begin{array}{l}\text { Často mám pocit, že se rodina bez } \\
\text { mé pomoci nemúže obejít. }\end{array}$ & 1 & 2 & 3 & 4 & 5 \\
\hline $\begin{array}{l}\text { Nastávají situace, kdy přebírám za } \\
\text { rodiče zodpovědnost (např. } \\
\text { vyřizuji za rodiče platby za } \\
\text { domácnost, pomáhám jim v jejich } \\
\text { zaměstnání). }\end{array}$ & 1 & 2 & 3 & 4 & 5 \\
\hline $\begin{array}{l}\text { Někdy vypomáhám rodičům } \\
\text { s penězi (např.: nakoupím ze } \\
\text { svých úspor, peníze rodičům } \\
\text { půjčím). }\end{array}$ & 1 & 2 & 3 & 4 & 5 \\
\hline
\end{tabular}

Nyní se prosím zamysli, do jaké míry tyto výroky vystihují tvého tátu.

Zakroužkuj tu variantu, která ti nejlépe sedí.

\begin{tabular}{|c|c|c|c|c|c|}
\hline & $\begin{array}{c}\text { Úplně to } \\
\text { na mě } \\
\text { sedí }\end{array}$ & $\begin{array}{c}\text { Spíš to } \\
\text { na mě } \\
\text { sedí }\end{array}$ & $\begin{array}{l}\text { Někdy to } \\
\text { na mě } \\
\text { sedí, } \\
\text { někdy ne }\end{array}$ & $\begin{array}{l}\text { Spíš to } \\
\text { na mě } \\
\text { nesedí }\end{array}$ & $\begin{array}{c}\text { Vůbec to } \\
\text { na mě } \\
\text { nesedí }\end{array}$ \\
\hline $\begin{array}{l}\text { Táta ode mě chce poradit ve } \\
\text { věcech, o kterých si myslím, že by } \\
\text { se měl radit s mámou, nebo } \\
\text { s jinými dospělými. }\end{array}$ & 1 & 2 & 3 & 4 & 5 \\
\hline $\begin{array}{l}\text { Táta se mně chodí svěřovat se } \\
\text { svými starostmi. }\end{array}$ & 1 & 2 & 3 & 4 & 5 \\
\hline Pokud tátu něco trápí, utěšuju ho. & 1 & 2 & 3 & 4 & 5 \\
\hline
\end{tabular}


TESTFÓRUM, 2020, č. 13, s. 31-60

www.testforum.cz

L. Pivodová, P. Daňsová, L. Lacinová: Dotazník zmatení rolí pro adolescenty: Sdělení o vývoji sebeposuzovací metody

\begin{tabular}{|c|c|c|c|c|c|}
\hline $\begin{array}{l}\text { Táta mě říká, že jsem stejný/stejná } \\
\text { jako máma. }\end{array}$ & 1 & 2 & 3 & 4 & 5 \\
\hline $\begin{array}{l}\text { Když tátovi máma chybí, } \\
\text { nahrazuje její přítomnost mojí } \\
\text { (např. díváme se spolu na filmy, } \\
\text { které se líbí tátovi, obejme mě, } \\
\text { když je mu smutno,...). }\end{array}$ & 1 & 2 & 3 & 4 & 5 \\
\hline
\end{tabular}

